\title{
DE CANGUILHEM A FOUCAULT, EM TORNO DA PSICOLOGIA
}

Marcio Luiz Miotto ${ }^{46}$

Resumo: O presente trabalho pretende comparar o debate ocorrido entre Georges Canguilhem e Robert Pagès em Qu'est-ce que la Psychologie?, de 1956, com os escritos de Michel Foucault publicados nos anos 1950. Para isso, após alguns apontamentos históricos, faz-se uma breve análise dos textos de Foucault publicados em 1954, Maladie Mentale et Personnalité e a Introduction à Le Rêve et l'Existence. Os textos de Foucault são então confrontados com o debate entre Canguilhem e Robert Pagès, que por sua vez são analisados e comparados com outros dois textos de Foucault publicados em 1957, La Psychologie de 1850 à 1950 e La Recherche Scientifique et la Psychologie. Tenta-se mostrar que o início da trajetória de Foucault não apenas dialoga com diversos temas sobre a Psicologia e as Ciências Humanas colocados por Canguilhem e Pagès, mas também ensaia respostas cujo teor será mais visível em Folie et Déraison e na Introduction à l'Anthropologie de Kant.

Palavras-chave: Michel Foucault - Georges Canguilhem - Robert Pagès - Psicologia - Ciências Humanas - Filosofia francesa contemporânea.

O presente trabalho pretende analisar a questão ética e epistemológica da Psicologia e das Ciências Humanas a partir da célebre conferência de Georges Canguilhem (1904-1995), Qu'est-ce que la Psychologie?, enunciada em 18 de dezembro de 1956 e, a partir desses temas, fazer uma análise precisa de sobre como o “jovem” Michel Foucault (1926-1984) compôs suas questões "antropológicas" nos primeiros escritos publicados nos anos 1950, antes e durante a estadia na Suécia. O objetivo principal não é, desse modo, deter-se nas relações integrais - que perduram por décadas - entre os pensamentos de Canguilhem e Foucault, nem de estabelecer continuidades de interlocução pessoal que não existiram até a escritura de Folie et Déraison. Tampouco se trata de apenas delinear integralmente o estatuto da psicologia nesses dois autores. No presente momento, trata-se de realçar dois outros problemas: 1) em que sentido as posições dos primeiros textos publicados de Foucault, que envolvem também um debate em torno da psicologia, dizem respeito aos compromissos mais alargados de uma fundação, e depois de uma contestação, das ciências humanas e dos antropologismos filosóficos; e 2) em que sentido esses textos, em pleno caminho a uma história da loucura, poderiam ser lidos como uma espécie de resposta às mesmas questões éticas e epistemológicas sobre a Psicologia colocadas pela conferência de Canguilhem. Em jogo estão os compromissos iniciais de Foucault em tentar fundar uma visão de homem uma "antropologia" - que dê suporte às ciências humanas em geral e à psicologia em particular. Compromissos iniciais cujo tom mudará rapidamente, quando essas tentativas iniciais de fundar as ciências humanas se converterão na crítica ao próprio debate em torno do

\footnotetext{
46 Professor Adjunto de Fundamentos Filosóficos da Psicologia (UFF-RPS).
} 
homem moderno. Em suma, trata-se aqui de evidenciar os compromissos do "jovem" Foucault contrapondo-o com o debate colocado por Canguilhem, inclusive para realçar como Foucault julga necessário ultrapassar um nível epistemológico para dar conta da questão antropológica sob um outro nível, doravante chamado de "arqueológico".

Dados os termos, cabe analisar preliminarmente as posturas do "jovem" Foucault, demonstrando a economia sob a qual o tom de seus escritos muda da "fundação" (textos de 1954) à "crítica" (textos de 1957). No entretempo dessas argumentações ocorre a conferência de Canguilhem, bem como a breve polêmica entre Canguilhem e Robert Pagès em Quelques remarques sur 'Qu'est-ce que la Psychologie?' ${ }^{47}$.

Entre Canguilhem e Pagès estão em jogo temas como o da fundação, a unidade e o papel prático da Psicologia. Temas ricos em consequências, especialmente se confrontados com as considerações do "jovem" Foucault, que ensinava Psicologia em Lille e na ENS entre 1952 e 1955 e se deparava com o mesmo universo de problemas. Conforme sugerido, a confrontação dessas posturas permite demonstrar diversos termos sob os quais, já nos escritos dos anos 1950, Foucault julga preciso ultrapassar um nível de análise epistemológico para dar conta dos conhecimentos sobre o homem, apontando questões que serão aprofundadas em suas teses sobre a loucura e Kant. Na resposta de Foucault aos termos colocados por Canguilhem e Pagès, também é possível destacar como Foucault começa a responder singularmente às mesmas questões fundamentais da Psicologia, sobre sua unidade, cientificidade e implicações éticas (e também políticas, conforme já comentou Braunstein ${ }^{48}$ ).

Seguindo tais interrogações, a primeira parte do artigo analisará alguns aspectos históricos e gerais dos dois projetos antropológicos publicados por Foucault em 1954. Em seguida, trata-se de analisar a conferência de Canguilhem e a resposta de Pagès, extraindo daí as questões da Psicologia e de certos debates correntes nos anos 1950-1960. Reunidas tais questões, os textos de Foucault publicados em 1957 até Folie et Déraison e Introduction à l'Anthropologie de Kant serão lidos ao mesmo tempo como uma "autocrítica" de Foucault às posições de 1954 e uma resposta às questões epistemológicas então colocadas. Tem-se, nesse caminho, parte dos fatores que conduzem Foucault da "fundação" à "crítica" dos antropologismos.

\section{ALGUMAS CONSIDERAÇÕES HISTÓRICAS}

Alguns dados históricos são importantes para fixar os termos. Em primeiro lugar, é pouco provável que Foucault tenha se deparado, ao menos diretamente, com a conferência de Canguilhem. Se nos fiarmos na biografia de Eribon ${ }^{49}$, durante os anos 1950 Foucault teve

\footnotetext{
${ }^{47}$ PAGÈS, “Quelques remarques sur 'Qu'est-ce que la psychologie?'”, p. 87-97. "Les remarques de M. Robert PAGÈS sont l'élaboration et le développement de son intervention dans la discussion qui suivit la conférence du Collège Philosophique" (Cf. la note de Canguilhem sur l'intervention de Pagès, p. 98).

48 BRAUNSTEIN, "La Critique Canguilhemienne de la Psychologie”, p. 181-190.

${ }^{49}$ ERIBON, Michel Foucault (1926-1984).
} 
"algum" acesso aos escritos de Canguilhem por meio de Althusser. Numa carta de Foucault enviada a Canguilhem durante junho de 1965, consta:

Quando comecei a trabalhar, faz dez anos, eu não o conhecia nem conhecia seus livros. Mas não teria feito o que fiz se não os tivesse lido. (Meu trabalho) traz sua marca profunda. Não sei bem dizer como, nem em que lugares exatos (...) porém o senhor deve perceber que (...) minhas "contraposições” (...) só são possíveis a partir do que o senhor fez, dessa camada de análises que o senhor introduziu, dessa "eidética epistemológica" que o senhor inventou..$^{50}$

Durante a conferência de Canguilhem, em 18 de dezembro de 1956, Foucault provavelmente estava entre Uppsala e Paris, enquanto a publicação da conferência em 1958 já coincidia com a interlocução de Foucault - que já tinha vários escritos de Folie et Déraison - com Canguilhem, embora nesse ano Foucault também partiu da Suécia para Varsóvia. De todo modo, independente do resultado, é possível dizer - veremos - que em diversos níveis as preocupações de Foucault, no mesmo período, ligam-se diretamente com o mesmo universo de questões da conferência, tais como a da unidade e do princípio lógico da Psicologia, a do fundamento das ciências humanas e a de suas aplicações práticas e consequências éticas e políticas.

Em segundo lugar, se a breve polêmica entre Canguilhem e Pagès data de 1956, essa data por assim dizer separa duas séries de publicações dos primeiros textos de Foucault, pois ele publicou seus dois primeiros textos em 1954 e outros dois em 1957. Em 1954 ele publica seu primeiro livro, Maladie Mentale et Personnalité, e uma longa Introduction à Le Rêve et l'Existence, texto fundador da Daseinsanalyse escrito por Ludwig Binswanger. E em 1957 aparecem dois artigos: La Recherche Scientifique et la Psychologie e La Psychologie de 1850 à 1950.

O texto de La Psychologie de 1850 à 1950 foi escrito entre 1952 e 1953 e reunia algum conteúdo das aulas de Foucault na Universidade de Lille e na ENS. Mas, publicado apenas em 1957, esse texto se avizinha mais das posições de La Recherche Scientifique et la Psychologie (também publicado em 1957) do que dos textos de 1954. De saída, vale fixar que o resultado dessas datas é importante: um texto publicado em 1957 apresenta dados pensados por Foucault em seus cursos, anteriormente às publicações de 1954 e com compromissos diversos delas (o que significa que no início dos anos 1950 Foucault não cultivava apenas as posições apresentadas em 1954). Além disso, Jean-François Braunstein alinha esses dois textos de 1957 como "alimentados" pela conferência de Canguilhem de 1956, no que configuraria uma "critique 'gauchiste' de la psychologie" 51 . Mas, como se vê, Foucault teria escrito esses textos bem antes. Recordando-se da situação, Denis Huisman, que encomendou o texto a Foucault, escreve: Foucault "era na época chefe do laboratório de psicologia da ENS - Rue d'Ulm - e assistente de psicologia na Universidade de Lille onde ele inaugurava um Instituto de Psicologia novo em folha. O artigo foi escrito em 1952-1953 e me foi enviado em 1953" ${ }^{\prime 2}$.

\footnotetext{
${ }^{50}$ ERIBON, Michel Foucault (1926-1984), p. 112.

${ }^{51}$ BRAUNSTEIN, “La Critique Canguilhemienne de la Psychologie”, p. 181.

${ }^{52}$ HUISMAN, "Note sur l'article de Michel Foucault”, p. 177.
} 
Conforme David Macey ${ }^{53}$, entre o fim de 1952 e o início de 1955 o jovem filósofo dividia seu tempo dando aulas de psicologia em Lille (ali passava "duas ou três noites na semana" em um hotel) e na École Normale (onde foi "répétiteur agrégé" convidado por Althusser). Depois da publicação de Maladie Mentale et Personnalité, afirma Eribon ${ }^{54}$, Foucault discutia frequentemente sobre psicologia com Jean Hyppolite. Em fevereiro de 1955, Hyppolite, tornado diretor da ENS, planejava reunir na instituição um círculo de estudiosos de Filosofia e Psicologia. André Ombredane, um dos fundadores do CERP (Centre d'Etudes et Recherches Psychotechniques) com Jean-Marie Faverge, coordenou ali desde essa época um seminário de Psicologia. Foucault participou de uma primeira reunião em fevereiro, com Ombredane, Hyppolite e outros. Mas ainda em 1954 recebeu um convite de Georges Dumézil para ocupar os cargos de diretor da Maison de France e "lecteur" na Universidade de Uppsala. Em agosto de 1955 Foucault assumiu as funções na Suécia, num período que duraria três anos, com pesquisas na biblioteca de Eric Waller em Uppsala e visitas de verão aos Archives Nationales e à biblioteca do Arsenal ${ }^{55}$. Desde então recebeu, até a ida à Polônia em 1958, diversas visitas de conferencistas, incluindo Hyppolite. E conforme mencionado, em 1958 sai da Suécia e vai a Varsóvia, onde revisa Folie et Déraison e envia no fim de 1958 um espesso manuscrito a Georges Canguilhem. No fim de 1959 vai a Hamburgo, onde se dedica à Introdução à Antropologia de Kant e elabora sua tradução.

Diante desse panorama, importa verificar as diferenças entre os textos de 1954 (que apresentam propostas “antropológicas”) e 1957 (que começam a criticar a Psicologia), e entre eles o debate Canguilhem-Pagès. Considerando os dois textos publicados por Foucault em 1954, cada qual possui projetos diversos e inclusive antagônicos: o primeiro texto, Introduction à Le Rêve et L'Existence, critica os objetivismos e naturalismos do século XIX em nome de uma "antropologia" de base fenomenológico-existencial que daria conta das contradições das ciências humanas. Já Maladie Mentale et Personnalité inverte os valores: o livro critica inclusive as abordagens existenciais, advogando uma ultrapassagem das "dimensões psicológicas" da doença mental em direção a certo viés correlato ao materialismo dos psiquiatras marxistas e pavlovianos dos anos 50, ligados ao Partido Comunista Francês, ao fim do regime de Stalin e à revista La Raison, em voga naquela época, mesmo que Foucault tenha saído do PCF em outubro de 1952 (Foucault adere ao PCF em 1950 e sai em outubro de 1952. Em 1953, ainda apresentou seminários sobre Pavlov aos alunos da $\mathrm{ENS}^{56}$ ).

\section{O "JOVEM" FOUCAULT: DO FUNDAMENTO ANTROPOLÓGICO À INQUIETUDE SOBRE AS CIÊNCIAS HUMANAS}

Segundo a Introduction à Le Rêve et l'Existence, todo o debate do século XIX e XX não teria superado, na parte ou no todo, os problemas do naturalismo. Contra o naturalismo, a perspectiva fenomenológico-existencial de Binswanger representaria o reatamento com uma

\footnotetext{
53 MACEY, Las Vidas de Michel Foucault, p. 91.

${ }^{54}$ ERIBON, Michel Foucault (1926-1984), p. 83-84.

${ }^{55}$ MACEY, Las Vidas de Michel Foucault, p. 120; FOUCAULT, Dits et Écrits (Vol. I), p. 24.

${ }^{56}$ Cf. "Chronologie" em FOUCAULT, Dits et Écrits (Vol. I), p. 18-21.
} 
tradição esquecida. Essa tradição concedia às imagens do sonho uma espessura ou consistência próprias, e não apenas o estatuto de um índice sem sentido próprio apontando para significações objetivas. Dar consistência às imagens do sonho, considerar o sonho como experiência de primeira ordem, significaria contornar análises de cunho naturalista, que relegam sempre o significado das imagens sonhadoras ao tema da exterioridade - o sonho como mero efeito de movimentos fisiológicos corporais, resultado das "associações" sensoriais ou índice objetivo de um aspecto inconsciente da mente. O sonho considerado como experiência por excelência - e não mero índice objetivo - seria um fator privilegiado para demonstrar como, para além da simples oposição entre a vida consciente e o corpo fisiológico dormindo, haveria um núcleo existencial anterior às divisões entre vigília e sonho, consciência e corpo, sujeito e objeto. "Existência" na qual o Dasein continuamente ultrapassa a si mesmo constituindo-se como "ser-no-mundo". Se o homem sonha, o sonho não seria o recuo da consciência em direção à fisiologia do corpo ou a significações inconscientes, mas exemplar das direções fundamentais nas quais o próprio mundo existencial se constitui e se configura (em seu "encantamento ou tormento", diria Binswanger alardeando aos modos "autênticos" e "inautênticos" detectáveis sob as narrativas sonhadoras ${ }^{57}$ ), independente do homem estar sonhando ou em vigília.

Vê-se como o "sonho" permitiria a Foucault (por meio de Binswanger) explorar uma questão mais fundamental, a da própria existência. Se o mundo existencial é capaz de se fechar no aspecto de uma "alienação" privada do louco ou se abrir ao mundo "comum" com os outros, tem-se na noção de existência como transcendência no mundo o fundamento de uma antropologia existencial. Esse novo fundamento desmistificaria as outras psicologias, unificaria o estudo do Homem sob uma antropologia mais autêntica e, sob uma nova teoria da expressão, embasaria novas práticas, da arte à clínica, chegando à constituição de um mundo autenticamente "comum".

Mas publicado no mesmo ano e em via contrária da Introdução a sonho e existência, Maladie Mentale et Personnalité denota outro projeto crítico e unificador. Segundo o livro, todas as psicologias - inclusive as fundamentadas na fenomenologia existencial ${ }^{58}$ - incorreriam num prejuízo comum, um ponto cego: sempre mais ou menos presas em certo primado da individualidade, as psicologias ignorariam as significações exteriores ao louco, e que constituem para além do indivíduo as dimensões da loucura como doença e desvio. Não é na loucura enquanto anormalidade individual que figuraria a chave da doença mental; essa chave residiria nas significações da sociedade ocidental que deram à loucura o significado de alienação, desvio e doença. Para além da individualização psicológica do anormal, aparece então a importância de uma análise histórica que acuse as garantias fictícias das sociedades burguesas. Conforme se pode entrever, a démarche de Foucault carrega um marxismo implícito ligado aos psiquiatras soviéticos que, em 1950, organizaram uma Session Scientifique em torno de Stalin e de Pavlov ${ }^{59}$. Conforme esse argumento, se de direito as conquistas burguesas do século XVIII definiram direitos universais do homem, o que ocorreu de fato é que esses direitos não

\footnotetext{
${ }^{57}$ Cf. BINSWANGER, “O sonho e a existência”, p. 441.

${ }^{58}$ Vale notar que essa crítica, feita ao mesmo tempo da Introduction à le Rêve et l'Existence, permanece na edição de 1962 de Maladie Mentale et Psychologie.

${ }^{59}$ MIOTTO, O problema antropológico em Michel Foucault, e PALTRINIERI, De quelques sources de Maladie Mentale et Personnalité. Réflexologie pavlovienne et critique sociale.
} 
passaram de abstrações intervenientes em um meio social, econômico e político repleto de contradições concretas. Foucault afirmava, no tom dos artigos correntes na revista La Raison: determinadas sociedades - leia-se "burguesas" - predispõem, de forma mais notável, altos índices de doença mental. A doença mental não se resume às dimensões psicológicas do doente, é preciso analisar o próprio meio sócio-histórico: ele é o responsável pelas contradições nas quais determinados homens teriam seus direitos alienados, criando as condições para que eles se tornem doentes e excluídos. O louco nada mais é do que o exemplo vivo das contradições sociais modernas - no limite, a contradição entre o ideal abstrato de uma humanidade de direito e a vivência incontornável da exploração do homem pelo homem de fato. E, por ser o louco esse exemplo vivo, que se pode apontar o dedo, é que se criou a instituição da exclusão, responsável por abstrair e individualiz̧ar as contradições.

O louco, portanto, vive apenas num momento segundo, como conflito interno, o que se dispôs primeiramente como as contradições externas de seu meio: "la condition première de la maladie est à trouver dans un conflit du milieu humain, et que le propre de la maladie est d'être réaction généralisée de défense devant ce conflit" ${ }^{\prime 60}$. Para completar a dimensão sócio-histórica desse meio, para fazer a ponte entre as contradições exteriores e a doença mental como conflito interior, o autor escolhido por Foucault é Pavlov, com sua unidade funcional entre o meio concreto e a fisiologia do organismo. Segundo o tom de Maladie Mentale et Personnalité, a psicologia soviética de Pavlov é a verdadeira responsável por resolver os problemas das ciências humanas e propiciar uma antropologia concreta isenta de abstrações individualizantes. Inclusive, a união desse viés socio-histórico com a fisiologia pavloviana tornaria possível uma reforma psiquiátrica, muito antes de Foucault ser lido pelos antipsiquiatras ("Les conséquences pratiques de ces idées seraient à trouver dans une réforme de structure de l'assistance médicale et des hôpitaux psychiatriques (...)" "61). Contra o projeto sobre Binswanger, o critério agora é outro: convém unificar a Psicologia e as Ciências Humanas desmistificando as abordagens errôneas e apelando a um viés socio-histórico amparado na Reflexologia.

Entre o projeto da fenomenologia existencial da Introduction a Binswanger e o viés pavloviano e socio-histórico de Maladie Mentale et Personnalité, o impasse é evidente. Trata-se de duas tentativas diversas de formular, praticamente ao mesmo tempo, uma antropologia fundadora. Mas a despeito das diferenças, trata-se igualmente de duas antropologias, duas perspectivas de homem que desmentiriam as demais e unificariam as Ciências Humanas e a Psicologia. Qual então seria a correta? Qual princípio antropológico definiria a psicologia una e verdadeira, a partir da qual as outras psicologias seriam desvios errôneos? Conforme Frédéric Gros já apontara, o antagonismo das duas propostas simultâneas contribuiria para criar uma inquietude que levaria à contestação de ambas:

[Em Maladie Mentale et Personnalité,] a ciência autêntica (não burguesa) garantia o único acesso possível ao homem verdadeiro, na medida em que prometia seu advento próximo. Mas [na introdução a Binswanger] o recurso paralelo a um estilo de análise

${ }^{60}$ FOUCAULT, Maladie Mentale et Personnalité, p. 108.

${ }^{61}$ FOUCAULT, Maladie Mentale et Personnalité, p. 109. 
fenomenológica devia conduzir a uma inquietude sobre esse sentido da loucura como doença mental (estimulada ainda pela leitura de Nietzsche). ${ }^{62}$

Em outras palavras: se o problema de fundar uma ciência humana admite ao mesmo tempo duas perspectivas igualmente válidas mas contrárias entre si, então ou as duas perspectivas anulam uma à outra, ou seu objeto é problemático, ou o problema foi inteiramente mal formulado. Como decidir?

\section{“LE SAVOIR N’A PAS D’ODEUR”}

Nesse plano de decisões e impasses abertos pelas posições de 1954, a conferência de Canguilhem em 1956 e sua breve polêmica com Robert Pagès permitem destacar críticas e comparações. Pode-se dizer que a conferência de Canguilhem critica as posturas empregadas por Foucault em 1954, quando propunha uma Psicologia unificadora. A pergunta do título - "O que é a psicologia?" - encontra eco no estatuto que se deve conferir ao princípio regedor das diferentes psicologias. Qual unidade lógica as rege? Que antropologia regeria as Ciências Humanas e a Psicologia, unificando as matérias em contenda? Canguilhem afirma: "Mas para a psicologia, a questão de sua essência, ou mais modestamente de seu conceito, põe em questão também a existência mesma do psicólogo, na medida em que na falta de poder responder exatamente sobre o que ele é, torna-se difícil a ele responder sobre o que faz " ${ }^{63}$.

Primeira questão abordada por Canguilhem: é possível que o psicólogo responda sobre "o que é e o que faz" quando se apoia em sua eficácia de perito ou expert. Mas a simples eficácia como essência lógica, ou o simples papel de técnico detentor de uma expertise, não concederiam à psicologia muito mais do que o estatuto de um "empirismo composto, literariamente codificado para fins de ensino" "64. Deixada a situação dessa forma, sob muitos aspectos os trabalhos de psicologia dariam a impressão de uma

filosofia sem rigor, uma ética sem exigência e uma medicina sem controle. Filosofia sem rigor, pois eclética sob pretexto de objetividade; ética sem exigência, pois associando experiências etológicas elas mesmas sem crítica, a do confessor, do educador, do chefe, do juiz etc.; medicina sem controle, pois das três espécies de doenças mais ininteligíveis e menos curáveis, as doenças de pele, doenças dos nervos e doenças mentais, o estudo e o tratamento das duas últimas sempre forneceram à psicologia observações e hipóteses.

[philosophie sans rigueur une étique sans exigence et une médecine sans contrôle. Philosophie sans rigueur, parce qu'éclectique sous prétexte d'objectivité; étique sans exigence, parce qu'associant des expériences éthologiques elles-mêmes sans critique, celle du confessur, de l'éducateur, du chef, du juge, etc.; médecine sans contrôle, puisque des trois sortes de maladies les plus inintelligibles et les moins curables, maladies de la peau, maladie des nerfs et maladies mentales, l'étude et le traitement des deux

\footnotetext{
${ }^{62}$ GROS, Foucault et la Folie, p. 26, grifos meus.

${ }^{63}$ CANGUILHEM, “Qu'est-ce que la Psychologie?”, p. 77, grifos meus.

${ }^{64}$ CANGUILHEM, “Qu'est-ce que la Psychologie?”, p. 77.
} 
dernières ont fourni de toujours à la psychologie des observations et des hypothèses. $]^{65}$

Novamente, é preciso encontrar a unidade lógica que dá conta do estatuto epistemológico da psicologia e, assim, dos princípios éticos que unificam suas diversas práticas. Pois, segundo as palavras de Canguihem, sem definir "o que é", fica difícil ao psicólogo responder sobre "o que faz".

Canguilhem considera outra possibilidade. Para além da eficácia, poderia-se então agrupar as psicologias discordantes e chamar de psicológico o domínio inteiro das psicologias, ou criar algum conceito mediador entre as teorias antagônicas. Mais do que ciência natural ou humana, a psicologia seria natural $e$ humana. Esse seria em linhas gerais o projeto de Daniel Lagache quando, em L'Unité de la Psychologie, ele unificou as perspectivas naturalistas e humanistas a partir da noção de "conduta significativa". Com tal noção, Lagache buscaria "integrar a noção de comportamento watsoniano" com as "categorias de sentido" das teorias psicanalíticas e humanistas ${ }^{66}$. Se o homem é ao mesmo tempo comportamento $e$ sentido, teria-se a proposta de unidade. Mas Canguilhem chama a atenção: dadas as partes conflitantes, essa unidade parece mais um "pacto de coexistência pacífica concluído entre profissionais do que uma essência lógica, obtida pela revelação de algo constante numa variedade de casos" ${ }^{67}$. O próprio " $\mathrm{e}$ " põe o problema: se grosso modo o homem é definido ao mesmo tempo como natural "e" humano, determinado "e" livre, objeto "e" sujeito, questões essenciais como a passagem do comportamento animal à linguagem humana, ou a passagem da natureza à cultura permaneceriam ainda não respondidas. "Mas então", afirma Canguilhem, "a psicologia não pode, para se definir, prejulgar aquilo que ela é chamada a julgar" ${ }^{\text {"68}}$. Ou em outras palavras, não se responde uma questão disjuntiva quando apenas se justapõe (com um " $e$ ") na resposta os mesmos elementos que já estavam presentes na pergunta.

A questão sobre se há fundamento na psicologia leva Canguilhem a esboçar uma curta história dessa ciência. É preciso "pesquisar se é ou não a unidade de um projeto que poderia conferir unidade eventual às diferentes espécies de disciplinas ditas psicológicas". Deve-se esclarecer "se os projetos se encontram" " Ora, é o princípio regedor desse encontro que regerá o que as psicologias "são" e o que "fazem". A história esboçada na conferência mostra que os diversos enraizamentos doutrinários das psicologias não permitem um encontro: segundo suas implicações históricas, as diversas psicologias se dividiriam em "ciência natural" (as psicofisiologias, reportadas em última instância ao legado aristotélico da alma como forma natural do corpo), "ciência da subjetividade" (as psicologias da consciência de si, reportadas às polêmicas em torno de Descartes) e "ciência das reações e do comportamento" (especialmente o behaviorismo, tornado possível com o desenvolvimento da indústria e o interesse pelo "caráter industrioso [e utilitário] da espécie humana"70). No

\footnotetext{
${ }^{65}$ CANGUILHEM, “Qu'est-ce que la Psychologie?”, p. 77.

${ }^{66}$ Cf. BERNARD, A Psicologia, p. 32.

${ }^{67}$ CANGUILHEM, “Qu'est-ce que la Psychologie?”, p. 78.

${ }^{68}$ CANGUILHEM, "Qu'est-ce que la Psychologie?”, p. 79.

${ }^{69}$ CANGUILHEM, “Qu'est-ce que la Psychologie?”, p. 79, grifos meus.

${ }^{70}$ CANGUILHEM, “Qu'est-ce que la Psychologie?”, p. 87.
} 
esquema de Canguilhem, as psicologias enquanto "ciência natural" e "da subjetividade" teriam certas justificativas relativas, por apresentar cada uma em seus enraizamentos filosóficos certa ideia de Homem (mesmo que eventualmente falha), embora não se alcance, ainda, unidade comum ${ }^{71}$. Mas com o behaviorismo é diferente: seu primado imediatamente prático, anti-filosófico e anti-especulativo andaria lado a lado com uma "incapacidade constitucional de apreender e exibir claramente seu projeto instaurador",72:

Aceitando tornar-se sob os auspícios da biologia uma ciência objetiva das aptidões, das reações e do comportamento, essa psicologia e esses psicólogos esquecem totalmente de situar seu comportamento específico em relação às circunstâncias históricas e aos meios sociais nos quais são conduzidos a propor seus métodos ou técnicas, e a fazer aceitar seus serviços.

[En acceptant de devenir, sur le patron de la biologie, une science objective des aptitudes, des réactions et du comportement, cette psychologie et ces psychologues oublient totalement de situer leur comportement spécifique par rapport aux circonstances historiques et aux milieux sociaux dans lesquels ils sont amenés à proposer leurs méthodes ou techniques et à faire accepter leurs services. $]^{73}$

O curioso é que a pergunta sobre a unidade (respondida com um "não") desliza à pergunta sobre o fundamento antropológico, e daí, na falta de um fundamento antropológico unificador para as psicologias, à denúncia de uma espécie de instrumentalismo presente em algumas delas, que inclusive careceriam de antropologia. O que quer dizer que Canguilhem situa, contra as psicologias da reação e do comportamento, as mesmas suspeitas colocadas no início da conferência contra toda a Psicologia: ao recusar qualquer ideia prévia de homem, ao não situar seu comportamento de pesquisador, essas psicologias e psicólogos não conseguiriam em última instância responder pelo que "são" e sobre o que "fazem". O homem apreendido como organismo em relação com um meio não recebe outro estatuto senão o de instrumento, pois sem definição antropológica prévia (e o behaviorismo inclusive recusaria uma fundação antropológica filosofante), caberia então manipular o homem sempre em função da adaptação a um "meio sócio-histórico" "74. Recusando a pergunta prévia sobre o homem, o psicólogo situaria o homem como instrumento, sem saber responder sobre o que ele - psicólogo, homem e portanto também instrumento - "ée" ou o que "faz".

Mas esse juízo contra o behaviorismo põe algo mais: ao situar os termos dessa forma, Canguilhem não termina a conferência respondendo à pergunta inicial, sobre se os diferentes projetos de psicologia se encontram. Ele já havia sugerido que não. Mas a questão da nãounidade se torna mais séria porque os perigos do homem-instrumento, entrevistos no behaviorismo, poderiam então assombrar a todas as psicologias. Nisso, conforme já

\footnotetext{
71 "Nos outros tipos de psicologia, a alma ou o sujeito, a forma natural ou a consciência de interioridade, eis o princípio que se dá para justificar sob valor uma certa ideia de homem em relação com a verdade das coisas" CANGUILHEM, “Qu'est-ce que la Psychologie?”, p. 89.

72 CANGUILHEM, “Qu'est-ce que la Psychologie?”, p. 87.

${ }^{73}$ CANGUILHEM, “Qu'est-ce que la Psychologie?”, p. 88.

${ }^{74}$ CANGUILHEM, "Qu'est-ce que la Psychologie?”, p. 89.
} 
comentou Braunstein ${ }^{75}$, e conforme já vimos na vinculação entre o "é” e o "faz", a crítica epistemológica se vincula inteiramente com uma crítica ética. Algumas psicologias fazem recurso a uma visão de homem, mas na ausência de uma resposta em última instância, unificada, sobre o que é o homem, este pode ser utilizado para inúmeros subterfúgios técnicos. Conforme sugerido, na ausência de um princípio lógico unificador, para além do caso do behaviorismo toda a psicologia correria o risco de ser, em última instância, uma Psicotécnica, eis a principal questão de Qu'est-ce que la Psychologie?. Testemunho disso é que, além das questões colocadas no início da conferência sobre a definição de psicologia carregar consigo tanto o que o psicólogo é quanto o que faそ, também a presença de Paul Guillaume um gestaltista - é posta junto aos exemplos do behaviorismo sobre o homem-instrumento. Guillaume também teria afirmado, em certo momento, que a recusa de um sujeito em responder um teste psicológico, sua resistência eventual ao teste, é uma prova de que a abordagem do psicólogo é verdadeira e o teste é eficaz. Mas sendo assim, o que responderia por essa "verdade" e "eficácia", definidos pela recusa da aplicação de uma objetividade científica, e não pela verificação em ato, positiva, aplicada, de seus conceitos? É como se a recusa de aplicar um método científico legitimasse sua própria verificação! Mas que regra mais fundamental, que inclusive dispensa o método científico, fundamentaria um valor positivo e científico para tal recusa do método científico? Novamente tem-se o perigo do homem-instrumento, figurado não apenas em possíveis abordagens instrumentais nãobehavioristas, mas na própria ausência de conceito unificador do campo. Pergunta Canguilhem ${ }^{76}$ : "onde querem ir os psicólogos fazendo o que fazem? Em nome de que eles se instituem psicólogos", em nome de que perspectiva antropológica - se isso servisse de justificativa - eles utilizam o homem como instrumento do próprio homem? Ou ainda, "dizme para que direção vais, para que eu saiba quem és?" "77. Conforme mostra o famoso desfecho da conferência, na falta de definir o princípio regedor de sua prática e incorrendo no perpétuo risco do homem-instrumento, fica ao psicólogo uma escolha igual à de quem sai do prédio da Sorbonne, em Paris: ele pode subir a ladeira em direção ao Panteão (lugar do saber e de grandes homens), ou descer a ladeira em direção à chefatura de polícia (lugar de controle social).

A julgar análises como as de Braunstein ${ }^{78}$ e Roudinesco ${ }^{79}$, segundo Canguilhem é para a chefatura que a Psicologia segue. Conforme sugerido, o problema epistemológico da ausência de unidade da Psicologia, colocado no início da conferência, acentuaria-se como problema ético, do homem transformado em instrumento: "O que Canguilhem chama aqui de psicologismo, isto é, um uso 'exorbitante' do cogito, não pode conduzir senão à aceitação e à submissão" "80. Em geral - embora mais visivelmente quando ligada ao cientificismo -, a Psicologia seria uma "anti-filosofia". Ideias como a da adaptação ao meio e da assimilação com a Psicologia animal (reduzindo a noção de "aprendizagem" à de "adestramento"), passando pelos ajustamentos em Psicologia do Trabalho, seriam opostas aos motivos

\footnotetext{
75 BRAUNSTEIN, "La Critique Canguilhemienne de la Psychologie”.

${ }^{76}$ CANGUILHEM, “Qu'est-ce que la Psychologie?”, p. 90.

77 CANGUILHEM, “Qu'est-ce que la Psychologie?”, p. 91.

78 BRAUNSTEIN, "La Critique Canguilhemienne de la Psychologie”.

${ }^{79}$ ROUDINESCO, Philosophy in turbulent times: Canguilhem, Sartre, Foucault, Althusser, Deleure, Derrida.

${ }^{80}$ BRAUNSTEIN, “La Critique Canguilhemienne de la Psychologie”, p. 187.
} 
mesmos de Canguilhem, segundo os quais "o conceito de sujeito, se existe em Canguilhem, (...) seria sem dúvida possível de definir mais precisamente ainda como um vivente resistindo às pressões do mundo e inventando suas próprias normas contra o meio" ${ }^{81}$. Roudinesco complementa:

pois, se Canguilhem nunca foi o teórico de uma filosofia de comprometimento subjetivo, ele permaneceu durante sua vida, e à maneira de Spinoza, um filósofo da rebelião (...) É por isso que ele via a psicologia, na medida em que é a disciplina do comportamento, adaptação e condicionamento, como uma escola de submissão e de supressão da liberdade ${ }^{82}$.

Nisso, não apenas a ausência de unidade e o risco da redução à Psicotécnica seriam reprováveis, mas a própria tentativa da Psicologia em imitar os discursos das ciências clássicas:

A psicologia é para ele o espírito de submissão que pretende justificar tudo em nome de uma certa seriedade da ciência. O psicólogo e o filósofo são para Canguilhem as duas figuras possíveis da relação com o mundo: um aceita o mundo, em nome do espírito de seriedade, o outro resiste, em nome de um espírito de revolta.

[La psychologie est pour lui l'esprit de soumission qui prétend tout justifier au nom d'un certain sérieux de la science. Le psychologue et le philosophe sont pour Canguilhem les deux figures possibles du rapport au monde: l'un accepte le monde, au nom de l'esprit de sérieux, l'autre y résiste, au nom d'un esprit de révolte. $]^{83}$

Considerando esses tons, a conferência de Canguilhem pode ser lida contra ambos os textos publicados por Foucault em 1954. Nos dois textos, Foucault buscava uma antropologia fundadora (existencial de um lado e marxizante de outro), o que, segundo Canguilhem, ao menos seria melhor do que o behaviorismo e a ideia do homem-instrumento. Igualmente, a recusa do instrumentalismo seria contornada pela ideia de uma existência mais autêntica (na Introdução a Binswanger) e de um pensamento sócio-histórico (no livro que chega a recorrer a Pavlov). Mas a questão mais fundamental se impõe: o resultado final apenas poderia ser a "inquietude", pois cada Psicologia, considerada por si própria mais verdadeira, não responderia pelo campo polêmico que põe a existência de outras psicologias contrárias, mas ainda existentes e consideradas por si próprias igualmente "mais verdadeiras". Não basta o problema epistemológico, Canguilhem também mostrava que a ausência de resposta sobre o que a Psicologia efetivamente "é" como campo unitário impede a resposta sobre o que o psicólogo "faz" como agente etológico, abrindo novamente a questão da unidade epistemológica à do homem-instrumento. Mantidas as diferenças, o que responde pelo campo do estudo do homem? "Se não podemos definir essa psicologia por uma ideia

\footnotetext{
81 BRAUNSTEIN, "La Critique Canguilhemienne de la Psychologie”, p. 188.

82 ROUDINESCO, Philosophy in turbulent times..., p. 25.

83 BRAUNSTEIN, "La Critique Canguilhemienne de la Psychologie”, p. 188.
} 
de homem, isto é, situar a psicologia na filosofia, não temos então o poder de proibir a quem quer que seja de se dizer psicólogo e de chamar de psicologia o que faz" ${ }^{\prime 4}$.

Dadas as posturas de Canguilhem, Robert Pagès responde-as em várias frentes, em defesa da Psicologia, de sua unidade (mesmo que possível), de sua objetividade e de sua prática. Por exemplo, já se acusou a Psicologia de não possuir unidade metodológica, por exemplo quando Canguilhem acusava ser impossível a "unidade da Psicologia" proposta por Lagache. Mas, se é possível descrever o comportamento humano, não se poderia então descartar a possibilidade do experimento: "todo domínio de descrição pode, em princípio, tornar-se experimental", do mesmo modo que "os acontecimentos atuais tendem a provar que uma astronomia experimental não é tão utópica" ${ }^{85}$. Disso, se o homem pode ser definido como um "conjunto particular de propriedades operacionais", isso não poderia ter outro conteúdo ou campo de aplicação do que o próprio trabalho científico, que a partir de si próprio "não tem nenhuma tendência de se especificar numa filosofia do homem-instrumento, por exemplo" ${ }^{\prime 86}$. Pagès, em primeiro lugar, tenta recuperar a credibilidade da ciência para afirmar: em si mesma, a racionalidade científica não exige o homem-instrumento; uma vez que pode haver descrição em Psicologia e a questão da descrição não afasta de direito a possibilidade do experimento, é possível ao menos pensar numa ciência não implicada com o homeminstrumento.

Ou ainda: mesmo que as psicologias sejam historicamente heterogêneas, não deixariam de existir diversas aproximações e fusões. Os testes invadiram a psicopatologia e a psicologia social, ou a Psicanálise influenciou boa parte da psicologia animal e experimental, por exemplo. Se não há unidade, poderia-se ao menos afirmar que as interligações ou "anteparos" [cloisons] "existem e parecem se desenvolver" 87.

Além disso, especialmente importante contra o argumento de Canguilhem, é que - conforme sugerido acima - a falta de definição de fundo da psicologia não a conduz necessária e suficientemente ao instrumentalismo. "O saber não tem odor", afirma Pagès ${ }^{88}$. Não há "vínculo de tipo lógico entre o domínio dos métodos da psicologia de um lado e uma filosofia do homem-instrumento de outro" 89 . É certo que "os psicólogos trabalham para quem os paga e quem lhes serve", e há inclusive predominância de abordagens de adaptação e aprendizagem para fazer o indivíduo se adequar ao meio socio-técnico, o que se vê do mercado de trabalho à Guerra. Mas a Psicologia também pode conduzi-lo a quaisquer outros objetivos, desde à "resistência às técnicas de servidão" 90 até ao gozo individual ou à santidade ascética, contribuindo inclusive para uma "antropologia libertária" . Métodos semelhantes podem ser animados por valores subjacentes bastante diferentes, o que colocaria o esprit de serieux da ciência também a serviço da vida, contrariamente à posição de Canguilhem. Em suma, para Pagès, mesmo que não se tenha respondido ainda sobre o princípio básico da psicologia, não seria inerente a ela o risco

\footnotetext{
${ }^{84}$ CANGUILHEM, “Qu'est-ce que la Psychologie?”, p. 91.

85 PAGÈS, “Quelques remarques sur 'Qu'est-ce que la psychologie?"”, p. 93.

86 PAGÈS, “Quelques remarques sur 'Qu'est-ce que la psychologie?'”, p. 93.

87 PAGÈS, “Quelques remarques sur 'Qu'est-ce que la psychologie?"”, p. 95.

88 PAGÈS, “Quelques remarques sur 'Qu'est-ce que la psychologie?"”, p. 97.

89 PAGÈS, “Quelques remarques sur 'Qu'est-ce que la psychologie?"”, p. 96.

${ }^{90}$ PAGÈS, “Quelques remarques sur 'Qu'est-ce que la psychologie?"”, p. 96.

${ }^{91}$ Cf. PAGÈS, “Quelques remarques sur 'Qu'est-ce que la psychologie?'”, p. 97.
} 
do homem-instrumento. Ela conserva seu pleno estatuto de ser (ou de poder ser) uma ciência a partir de um princípio básico regedor, não precisando ser apenas um instrumento de controle social.

Portanto, contra Canguilhem, Pagès declara que, se é descritível, a Psicologia é passível de experimento e unificação. E como qualquer outra ciência, a Psicologia em si própria não precisa ser alienada, embora toda ciência possa ser alienável. Posição que, aliás, concordaria com os dois projetos de Foucault de 1954. Para Foucault, tanto a antropologia existencial, quanto a antropologia concreta de viés pavloviano-marxizante, teriam como tarefa tornar o homem mais "autêntico" ou mesmo "desaliená-lo", mostrando que haveria projetos psicológicos, antropológicos e emancipadores.

Como se sabe, Canguilhem concede a Pagès uma breve tréplica ${ }^{92}$. Anuente para com a posição de Pagès, ele chega a conceder a possibilidade de uma Psicologia teórica livre de inspirações psicotécnicas. Mas, em relação ao perigo sobranceiro do instrumentalismo, ele nunca poderia se fundar sobre uma "filosofia sistemática": "É porque sem dúvida estimo 'não-filosofia' uma construção, mesmo sistemática, que chegue a qualquer forma de segregação humana" "13. Se com essas palavras Canguilhem retirou a advertência de que a Psicologia poderia descer à "delegacia", ao invés de subir ao "Panteão", cabe ao leitor interpretar.

\section{"MAIS LES DIEUX NE SONT PAS LA"}

O debate entre Canguilhem e Pagès permite extrair diversos termos de comparação com o jovem Foucault. Conforme visto, em cada um dos textos de 1954, Foucault pretendia fundar a Psicologia por meio de uma teoria unitária (a reunir todo o campo do estudo do Homem) e desmistificadora (por descartar todas as outras psicologias). Contra isso, Canguilhem denunciaria, direta ou indiretamente, que a ausência de unidade lógica da Psicologia a despeito do eventual sucesso de psicologias particulares ameaçaria os direitos de todo o conjunto. A ambiguidade dos textos de 1954 o mostra: se o pavlovismo marxizante está correto, nada resta à fenomenologia existencial, e vice-versa. Mas para Foucault, a coexistência entre os projetos contraditórios testemunha uma "inquietude" que conduziu aos textos publicados em 1957 (escritos em 1952-1953!) e depois às teses de doutorado sobre a loucura e a antropologia de Kant. Em 1956 ele permaneceu a maior parte do tempo na Suécia, e conforme sugerido, ainda não há dados suficientes para afirmar sobre o quanto acompanhou o teor da conferência de Canguilhem enunciada em dezembro (o encontro efetivo entre os dois ocorreu mais tarde, para a relatoria de Folie et Déraison). De todo modo, a proximidade temática dos textos de 1957 com a conferência de 1956 é notável, a ponto de comentadores-biógrafos como José Luis Moreno-Pestaña ${ }^{94}$ afirmarem sobre coincidências "assombrosas", "esquemas de pensamento idênticos" ou um "habitus filosófico" persistente após a conferência de Canguilhem (sob o mesmo tom, Roudinesco chamava a atenção à conferência de Canguilhem ser adequada a certo clima dos "estudantes da Rue d'Ulm"

\footnotetext{
92 CANGUILHEM, “Qu'est-ce que la Psychologie?”, p. 98.

93 CANGUILHEM, "Qu'est-ce que la Psychologie?”, p. 98.

${ }^{94}$ PESTAÑA, Convirtiéndose en Foucault. Sociogénesis de un filósofo, p. 198.
} 
influenciados por Althusser e outras figuras como Saussure e Lacan ${ }^{95}$ ). E além do mais, a posição de Canguilhem colocava uma crítica e a resposta de Pagès uma defesa: sem responder sobre seu fundamento, segundo Canguilhem a psicologia correria o risco de não passar de uma psicotécnica do homem-instrumento, ao que Pagès respondia que o uso instrumental não era nem inerente à psicologia, nem ausente em qualquer outra ciência.

Como situar, contra tais fatores, a "inquietude" gerada pelos textos de 1954? As perspectivas humanistas negam as naturalistas (e vice-versa), e a conferência de Canguilhem ensinaria que nem a mera justaposição das teorias, nem a justaposição dos conceitos, dariam conta da paisagem conceitual das psicologias. Canguilhem circunscreveu as diversas psicologias em função de suas tradições filosóficas derivadas. Ele também termina a conferência dizendo que, sem uma definição precisa da Psicologia, "não temos então o poder de proibir a quem quer que seja de se dizer psicólogo e de chamar de psicologia o que faz", conforme já mencionado ${ }^{96}$. Mas, mesmo que o estatuto seja impreciso a ponto de qualquer um se arrogar o título de "psicólogo", permanece ainda um estatuto, o problema da paisagem conceitual inteira, o que Canguilhem chamava de "essência" ou "conceito" regedor da Psicologia como campo, seja ele disperso ou não. As psicologias podem derivar de tradições filosóficas distintas (ou até de tradição nenhuma, pois algumas supostamente derivariam de certa ideologia emuladora da indústria no século XIX), mas mesmo que as diferenças persistam, o que rege a unidade pela qual todas são estudos do homem chamados de psicologia?

Os dois textos de Foucault publicados em 1957 tratam desse problema. O artigo sobre La Psychologie de 1850 à 1950 - lembremos que foi encaminhado para publicação em 1953 ! - mostra que a inquietude frente às posições dos textos de 1954 já estava presente. Conforme o texto, a psicologia nasceu sob o signo de uma contradição: ela recebeu da Aufklärung a tarefa de alinhar-se com as ciências da natureza e encontrar no homem o prolongamento de leis naturais; mas essa situação mesma a forçou, por um "cuidado de fidelidade objetiva" ${ }^{97}$, isto é, pela própria necessidade de resolver o problema, a reconhecer na "realidade humana" uma complexidade maior do que a disponibilizada pelos modelos naturalistas clássicos, exigindo então novos projetos.

Essa teria sido a guinada das psicologias naturalistas do século XIX para o problema das "significações objetivas" do século XX (ao menos desde Dilthey-Husserl-Freud, mas incluindo também as reformulações naturalistas para além do determinismo clássico). As Psicologias do século XX precisaram criar novos métodos e conceitos para abordar as funções especificamente humanas no homem, o que os modelos clássicos do século XIX não conseguiam. Mas elas não deixaram, com suas renovações, de compor uma paisagem conceitual igualmente contraditória e discordante. Foucault nota algo a mais: o conteúdo dessas novas psicologias discordantes acaba repetindo o mesmo conjunto de contradições presentes anteriormente, no nascimento da psicologia. Entre a natureza e a humanidade, o determinismo e a liberdade, o indivíduo e a cultura - enfim, os mesmos problemas do século XIX -, algumas psicologias do século XX tendem para o elemento e outras à totalidade;

\footnotetext{
${ }^{55}$ Cf. ROUDINESCO, Philosophy in turbulent times..., p. 28.

${ }^{96}$ CANGUILHEM, “Qu'est-ce que la Psychologie?”, p. 91.

${ }^{97}$ FOUCAULT, Dits et Écrits (Vol. I), p. 148.
} 
umas priorizam a gênese e outras a estrutura; algumas o manifesto e outras o latente, umas prezam as instituições sociais e outras as condutas individuais etc., enfim, a paisagem psicológica reduplica as mesmas contradições que colocaram sua existência ${ }^{98}$, fazendo essas contradições avançarem sob novas potências. Mas se as diferentes psicologias adotam posições estratégicas dentro do grande problema, e se suas estratégias reeditam os mesmos problemas que deveriam ser respondidos, o que responde por esse curioso estatuto?

A conferência de Canguilhem já alertava, contra Lagache, que para julgar seus problemas, uma psicologia não poderia prejulgá-los, isto é, não poderia enunciar como resposta os mesmos conteúdos colocados pela pergunta ${ }^{99}$. Vimos isso no exemplo de L'unité de la Psychologie. Ali, Lagache empreendia termos como o de "conduta significativa", unificando com isso as tendências naturalistas ("conduta") e humanistas ("significação"), mas essa unificação apenas encaminhava como resposta o que ainda precisaria ser respondido: se o homem é, por exemplo, conduta natural $e$ significação humana, não se respondeu ainda pela passagem precisa entre natureza $e$ significação, animalidade e humanidade etc.. Nos termos de Canguilhem: como a Psicologia poderia prejulgar o que deveria ser chamada a julgar?

O Foucault de 1957 percorre a mesma linha: uma psicologia não poderia, para resolver o problema, simplesmente reduplicar o problema que lhe convém responder. Não será mais internamente, no seio de uma teoria antropológica escolhida como mais privilegiada do que as outras, que se decidirá sobre o estatuto das psicologias. Escolha-se a referência de uma teoria alinhada com o naturalismo ou o humanismo, com a subjetividade ou a objetividade, mesmo as psicologias mais atuais também reduplicam as mesmas contradições que geraram sua existência, reencontrando-as no interior de suas doutrinas finalmente "transpostas e travestidas"100. Por isso, em La Psychologie de 1850 à 1950 é preciso um movimento para fora - não se deve mais tomar um dos termos da polêmica, mas encarar a polêmica inteira. Não será mais uma psicologia privilegiada a detentora da fundação antropológica que resolverá o problema das antropologias. Não se resolverá mais o problema das ciências humanas dentro de uma perspectiva epistemológica, tal como proposto nos textos de 1954. Agora é preciso um deslocamento em direção à História. Daqui por diante é uma determinada situação histórica, e não mais uma ou várias psicologias mal esclarecidas ou mal enraizadas cientificamente, a responsável pela situação "inquietante” das psicologias e suas intermináveis polêmicas. Nos textos de 1954, por meio de uma perspectiva antropológica Foucault buscava fundar as ciências humanas; mas em La Psychologie de 1850 à 1950 importa analisar o teor de sua constituição histórica.

Isso já implica deslocamentos inclusive frente à polêmica entre Canguilhem e Pagès. Canguilhem fez uma análise histórico-epistemológica das Psicologias, reportando-as às suas diversas matrizes conceituais, mostrando que elas "não se encontram"; Pagès sustentava que, a despeito das diferenças, há também aproximações, e se é possível descrever a conduta, então é também possível uma ciência experimental e, por conseguinte, unitária. Na linha de

\footnotetext{
${ }^{98}$ FOUCAULT, Dits et Écrits (Vol. I), p. 163.

${ }^{99}$ CANGUILHEM, “Qu'est-ce que la Psychologie?”, p. 78-79.

${ }^{100}$ FOUCAULT, Dits et Écrits (Vol. I), p. 165. Os exemplos utilizados são a Cibernética e a Daseinsanalyse de Binswanger, que reinserem as ambiguidades da relação sujeito/objeto em "estimações estatísticas" ou num alargamento sob a noção de "existência", reiterando, novamente, um campo polêmico que transpõe as polêmicas que geraram o próprio campo...
} 
Canguilhem, Foucault também mostrou nesse texto enviado em 1953 - antes da conferência - que o impasse em Psicologia tem raízes histórico-epistemológicas distintas. Mas ele sugere algo mais: a "história" ali proposta, e que fecha o texto, não é apenas uma história das diferenças epistemológicas entre as psicologias, pois, para Foucault, essas diferenças epistemológicas acabam reatualizando, "transpostas e travestidas", as contradições que as ocasionaram. Isso significa dizer que a história proposta no fim de A Psicologia de 1850 a 1950, a história que pretende "levar a sério as contradições" humanas ${ }^{101}$, exige que se saia de uma escolha epistemológica que apenas reitera o problema que a colocou.

O outro texto publicado em 1957, La Recherche Scientifique et la Psychologie, aprofunda esse teor. A epígrafe do texto é uma citação de Jean Édouard Morère: há psicologias ancoradas no naturalismo ou no humanismo, na fisiologia ou no espírito, nas formas objetivas ou na vida interior. Mas há algo mais: "apesar de tudo há psicólogos, e que pesquisam" "102. A epígrafe parece resumir o movimento do texto inteiro: sempre se perguntou à Psicologia sobre seus direitos junto às outras ciências, ou igualmente, sempre se constatou suas variações e ambiguidades; mas para além de seus direitos, não faltaria então responder sobre sua existência efetiva? É preciso realçar a ironia ali presente: "Apesar de tudo, há psicólogos", a despeito de estabelecerem ou não seus direitos científicos; $e$ eles estão aí não apenas de direito, mas também de fato, $e$ pesquisam. O que responderia sobre suas condições de existência?

A situação que inicia o texto é banal: um professor de psicologia pergunta a seu aluno se escolherá a "psicologia filosófica" (como as inspiradas na fenomenologia), ou a "psicologia científica", aquela dos experts que imitam o naturalismo e vestem jaleco branco. Mas isso não seria estranho? Se um estudante pode escolher a psicologia "científica" ou a "filosófica", isso se deve a uma situação mais profunda - é porque "um dos a priori históricos da psicologia, em sua forma atual, é essa possibilidade de ser, sob modo de exclusão, científica ou não" ${ }^{103}$. Não se pergunta ao biólogo ou ao físico se desejam fazer ciência ou não, ou ao químico se ele prefere a química "científica" ou a alquimia, ou inversamente, ao pescador se deseja dar atenção de pescador ou de biólogo; mas a psicologia teria esse curioso estatuto de, sob modo de escolha e exclusão, abrir ou não um horizonte científico. Se é assim, então em psicologia a pesquisa não é científica de pleno direito, suas formas concretas não se articulam necessariamente sob o horizonte prévio e regedor da ciência, mas é a ciência que se coloca, posteriormente, a partir de uma escolha. Afirma Foucault: é preciso então interrogar a psicologia "sobre um fundamento que se sabe já não ser a objetividade constituída da ciência"104. Não é mais um debate sobre a solidez epistemológica que dará conta de tal fundamento, é preciso algo mais. Se Pagès dizia, por exemplo, a tese de que a Psicologia poderia vir a ser a formalização científica de uma prática qualquer, Foucault rebate essa tese severamente ${ }^{105}$ : não é a

${ }^{101}$ FOUCAULT, Dits et Écrits (Vol. I), p. 169.

102 FOUCAULT, Dits et Écrits (Vol. I), p. 165.

103 FOUCAULT, Dits et Écrits (Vol. I), p. 166.

${ }^{104}$ FOUCAULT, Dits et Écrits (Vol. I), p. 167.

105 Vide a ironia do exemplo do pescador, FOUCAULT, Dits et Écrits (Vol. I), p. 166: “Qu'on ne me dise pas pourtant que le mode de reproduction des mollusques d'eau douce peut concerner le pêcheur à la ligne, tout comme il appelle, invoque et retient l'attention, peut-être décennale, d'un naturaliste; car on ne me demandait pas si je m’intéressais à mon âme pour assurer son bonheur et faire mon salut, ou pour en expliciter le Logos”. 
formalização científica de uma prática, mas a "escolha" para que uma eventual prática possa vir a ser psicológica e, caso se "opte” mais uma vez, científica ou não (pois a prática pode ser psicológica sem ser científica).

Vê-se o índice desse "fundamento" externo à objetividade científica em diversos fatores. Em primeiro lugar, as relações entre teoria e teoria em psicologia seriam notavelmente negativas. Não se trata de apenas constatar conflitos e diferentes enraizamentos, como em Canguilhem, ou aproximações, como em Pagès. Na história da psicologia, as relações de negação e refutação entre as diferentes teorias não deixariam entrever um elemento de positividade, ultrapassagem ou ampliação do conhecimento, como nas outras ciências ou na história. No âmbito de uma Ciência, seu "progresso" certamente ocorre contra os conhecimentos estabelecidos, sempre levando as hipóteses científicas mais adiante "às custas de uma objetividade reconhecida"; mas entre as conjecturas e refutações do cientista, no jogo de fazer avançar o conhecimento construído mediante conceitos permanece um elemento de positividade, pois a ciência sempre retoma o saber constituído "numa investigação mais geral e mais radical" "106. Igualmente, a História (Foucault se refere descritivamente às perspectivas dialéticas) ensina inúmeras rupturas e um movimento de sucessivas desmistificações, mas não o faz senão para mostrar o elemento positivo de uma "tomada de consciência progressiva" ${ }^{\prime 107}$.

Mas em Psicologia, não haveria uma positividade da psyché que permaneceria através das críticas e denotaria um progresso científico ou um telos sintético como o da História. Cada psicologia que critica as outras as invalida e redefine mais uma vez, de um só golpe, o problema de toda psicologia, que será criticado, invalidado e redefinido pela próxima

106 FOUCAULT, Dits et Écrits (Vol. I), p. 170. Foucault é bastante alusivo, mas um exemplar pode aclarar. Heidelberger (Some patterns of change in the Baconian Sciences of the early 19th century Germany) demonstra como, no século XIX, houve na Alemanha duas teorias conflitantes sobre a eletricidade, reunindo pensadores românticos de um lado e "cientificistas" de outro. Partidários de teorizações atomísticas ou dinâmicas, ambos os lados do litígio buscavam explicar os fenômenos elétricos reduzindo-os a determinadas entidades subjacentes. Mas entre uns e outros, analistas como Georg Simon Ohm estabeleciam modelos matemáticos que descreviam fenômenos elétricos sem a redução necessária a entidades fundamentais. Em suma: seja a eletricidade atomística ou dinâmica, os modelos de Ohm operam e fazem avançar as descrições, num campo polêmico no qual tanto reduções ontológicas quanto descrições matemáticas compartilham o mesmo universo de conceitos a resolver. Haveria então, entre os conceitos divergentes, um princípio de comunidade delimitado sob uma espécie de "positividade" que faz ambas as perspectivas operarem sob o nome de "Eletricidade". As descontinuidades teóricas não deixariam esquecer um campo de análise que as rege e permita chamar o conjunto dos conceitos sob um mesmo nome. Para Foucault, em Psicologia ocorreria algo diferente: é como se esse princípio positivo e mais básico de comunidade conceitual não existisse (ou ainda não fosse clarificado), e quaisquer das perspectivas (Behaviorismo, Psicanálise etc.), para se fazerem valer, substituíssem o campo de positividade inteiro, ao mesmo tempo definindo o campo e reduzindo as posições rivais a zero. Em Física, diferentes perspectivas seriam motivos de trabalho rendendo hipóteses e conjecturas para levar a ciência mais adiante, com suas (des)continuidades inerentes; em Psicologia, 1) uma perspectiva apenas funcionaria anulando todas as outras, apossando-se do campo inteiro do que deveria ser chamado de "psicológico", mas 2) não obstante continuaria convivendo com as outras, como se a existência de uma psicologia não reduzisse a outra à ilusão. Ou, em outras palavras, para a Física conjecturas diversas pertencem a um plano de debate; em Psicologia, teorias rivais implicam desmistificação total e irrestrita. E em Física, há um plano comum que permite refutar o atomismo e reforçar a dinâmica, por exemplo, enquanto em Psicologia ocorre uma espécie de persistência na qual as teorias ao mesmo tempo persistem, mas reduzem as teorias concorrentes a um zero: ao mesmo tempo guerra total, mas convivência morna.

${ }^{107}$ FOUCAULT, Dits et Écrits (Vol. I), p. 172. 
psicologia e assim por diante. O exemplar é a Psicanálise em relação às psicologias da consciência do século XIX: à luz das pesquisas psicanalíticas, os princípios das psicologias clássicas da consciência não são ampliados, mas desviados, invalidados e "curto-circuitados". Diante da descoberta freudiana do inconsciente, as psicologias da consciência seriam exemplares ou "casos" ilustrando o que a própria psicanálise revela: a ignorância do inconsciente aparece como "conduta de defesa", "reflexão censurada", enfim, uma teoria cuja ignorância do inconsciente se explica pelo recalque. Tudo se passa como se o tema da nova ciência (por ex., o do recalque) pudesse passar de suas análises internas para extrapolálas numa análise da própria ciência, transformada em objeto e reduzida então a uma mistificação, como se as psicologias que ignorassem a noção de recalque fossem, elas mesmas, espécies de psicologias recalcadas, portanto figurações que ficaram para trás e sem comunhão com a nova noção adquirida ${ }^{108}$. Em outras palavras, a psicanálise não denunciaria nas psicologias da consciência apenas um erro superável no progresso de um saber que conduziu a ciência adiante; em certo sentido ela é uma denúncia da ilusão ${ }^{109}$.

O exemplo da Psicanálise valeria para as outras Psicologias. Não há erro a ser completado no elemento de uma positividade, mas apenas a desmistificação de uma teoria tratada como ilusória, e reduzida a zero sob os temas da nova teoria. Denunciando a ilusão e não o erro, a relação entre as psicologias é negativa: para o behaviorista o psicólogo do século XIX sofre da ilusão da subjetividade; para o gestaltista o behaviorista padece da ilusão do elemento; para o psicólogo fenomenológico-existencial o cientista natural ilude-se na ignorância da consciência doadora de sentido e assim por diante, a crítica não toma o sentido de um fundamento, mas sim "a forma de uma negação", e assim

A psicologia não encontra jamais na psique senão o elemento de sua própria crítica. A crítica da história pela História tem um sentido de um fundamento, a crítica da psicologia a partir da psiquê não toma forma que não seja a de uma negação. É porque a pesquisa histórica, se ela se dá o aspecto de uma desmistificação, recebe pela mesma o valor de uma tomada positiva de consciência; a pesquisa científica, sob as mesmas espécies da desmistificação, não realiza mais do que um exorcismo, uma extradição de demônios. Mas os deuses não estão lá.

[La psychologie ne trouve jamais dans la psyché que l'élément de sa propre critique. La critique de l'histoire par l'Histoire a le sens d'un fondement, la critique de la psychologie à partir de la psyché ne prend jamais que la forme d'une négation. C'est pourquoi la recherche historique, si elle se donne l'allure d'une démystification, reçoit par la même valeur d'une prise de conscience positive; la recherche psychologique sous les mêmes espèces de la démystification n'accomplit jamais qu'un exorcisme, une extradiction des démons. Mais les dieux ne sont pas là.] $]^{110}$

Canguilhem, por exemplo, já apontara, mesmo que indiretamente, essa relação de negatividade entre as psicologias (no argumento de que elas não se encontram). Mas no nível

108 Cf. FOUCAULT, Dits et Écrits (Vol. I), p. 171.

${ }^{109}$ FOUCAULT, Dits et Écrits (Vol. I), p. 172.

${ }^{110}$ FOUCAULT, Dits et Écrits (Vol. I), p. 172-173. 
do "apesar de tudo, há psicólogos, e que pesquisam" - da Psicologia no nível de sua existência efetiva, para além da simples petição de seus princípios epistemológicos -, a negatividade não pareceria ainda suficientemente encarada. Cada Psicologia, considerada por si própria a mais correta, tem com as demais uma relação de guerra total (a vitória de uma garante a aniquilação - ou "exorcismo" - das outras sob os conceitos vencedores). Mas curiosamente, esse apelo à vitória total convive paradoxalmente com uma convivência morna, como se tudo pudesse ser definido não pelo combate, mas pelo aluno que "escolhe" a psicologia "científica ou não". Disso tudo, nesse ambiente negativo de guerra total e, não obstante, morna convivência, como foi possível esse curioso estatuto, diverso das outras ciências e da própria História? O que responde sobre essa curiosa existência efetiva, de guerra total mas de convivência morna?

Em segundo lugar, as relações entre teoria e prática, ou mais precisamente entre a psicologia e as outras ciências e práticas, também seriam negativas em psicologia. Isso porque, se por modo de escolha a psicologia pode ser ciência ou não, a história da Psicologia mostraria com inúmeros casos que a prática cotidiana a ser psicologizada não é necessariamente vinculada à formação teórica e de pesquisador; e vice-versa, a simples formação teórica também não garante, necessariamente, o acesso a um "exercício de psicologia onde prática e pesquisa se encontrariam efetivamente ligadas"111. Se não há vínculo necessário entre teoria e prática, é porque qualquer prática originalmente não psicológica poderia receber um ordenamento psicológico de uma psicologia qualquer, e virtualmente a psicologia pode ser chamada a "dizer a verdade discursiva" uma Psicologia. Os exemplos são a Psicologia Escolar, do Trabalho, a Psicometria e a Psicologia Clínica. Nelas, "o trabalho de pesquisa empresta sua positividade apenas a uma experiência que não é ainda psicológica, e suas possibilidades de aplicação são determinadas de avanço por uma prática extra-psicológica que empresta apenas a si mesma seus próprios critérios". Quando, por exemplo, a Psicologia chega ao espaço da clínica (que lhe existia anteriormente, com uma consistência histórica particular, ritos e positividades próprias), ela se resumiria a "fornecer a uma prática já constituída aperfeiçoamentos técnicos cuja validade será demonstrada pelo fato de que a clínica médica pode perfeitamente chegar sozinha aos mesmos resultados" ${ }^{\prime 113}$.

Aí reside o vínculo "negativo" entre teoria e prática: prática e teoria não se interdependem necessariamente e mutuamente, práticas não visam necessariamente teorias possíveis e teorias não visam necessariamente práticas disponíveis, mas a psicologia retira boa dose de sua validade por ser aplicável a qualquer prática possível. Nas palavras de Foucault,

Prática e pesquisa não dependem uma da outra senão sob modo de exclusão; e a psicologia "científica", positiva e prática se encontra assim reduzida ao papel

${ }^{111}$ FOUCAULT, Dits et Écrits (Vol. I), p. 175.

${ }^{112}$ FOUCAULT, Dits et Écrits (Vol. I), p. 177.

${ }^{113}$ FOUCAULT, Dits et Écrits (Vol. I), p. 176, grifos meus. 
especulativo, irônico e negativo de dizer a verdade discursiva de uma prática que se passa muito bem ${ }^{114}$.

Em sua conferência, Canguilhem dizia: na falta de dizer "quem é", fica difícil ao psicólogo dizer “o que faz". Na falta de unidade epistemológica (ou a despeito dela), incorrese no risco do homem-instrumento, do savoir-faire sem ciência, e contra isso Pagès respondia que a ciência não é em si alienante, e além disso, qualquer prática ingenuamente descritível poderia ser experimentalmente formalizável para alcançar o estatuto de teoria científica. Com base no argumento de Pagès, tome-se a Escola, a Fábrica e a Clínica, por exemplo: seriam campos virtualmente descritíveis, passíveis então de experimentação e, logo, de uma Psicologia unitária. Tudo se passa como se tais práticas carregassem, por si mesmas, as virtualidades de serem descritíveis por uma Psicologia, e então a Psicologia da Escola, do Trabalho e da Clínica seria uma espécie de herdeira natural desses espaços, a teoria que viria a dizer a verdade de tais práticas efetivas. Mas aqui Foucault empreende um outro artifício, também utilizado pela Epistemologia (e entrevisto também em seus cursos na ENS, por ex. em La Psychologie Génétique ${ }^{115}$ ), mas cujo desenvolvimento será um dos grandes motes de sua “arqueologia". Por exemplo, em L'Objet de l'Histoire des Sciences, de 1966 (e provavelmente já marcado pelo diálogo com Foucault), Canguilhem sugere como a Biometria e a Psicometria se tornaram possíveis a partir de historicidades heterogêneas e não científicas: "a história da introdução e da extensão das matemáticas probabilísticas na biologia e nas ciências do homem no século XIX”, "O objeto dessa história não pertence a nenhuma das ciências constituídas no século XIX; ele não corresponde a nenhum objeto natural cujo conhecimento seria a réplica" ${ }^{" 116}$, mas apenas a determinados eventos nos quais práticas não científicas, como a consolidação dos exércitos nacionais ou do ensino escolar primário, "tiveram por efeito fornecer à observação uma matéria homogênea e suscetível de um tratamento matemático". Em miúdos: nem na escola ou no exército, nem na "matemática de Laplace" ou na "biologia de Darwin" estão inerentemente inscritas as possibilidades de uma Biometria ou de uma Psicometria, não há em cada uma delas qualquer telos destinatário das ciências que depois surgiram, pois são campos disjuntivos e exteriores; mas uma análise efetiva dos encontros que geraram essas ciências apenas se torna possível quando, a partir de certa atualidade, o historiador busca as condições pelas quais a ciência se formou, inclusive no encontro com fatores não-científicos e heterogêneos.

Argumento semelhante está em jogo no texto de Foucault. Contra Pagès, não se trata de dizer que haveria uma espécie de telos a tira-colo em instituições ou práticas como a escola, a fábrica ou a clínica que poderia conduzir, como que por direito natural, a uma Psicologia unitária e experimental. E por outro lado, na história do Ocidente as teorias disponíveis sobre a alma também não autorizariam, necessária e suficientemente, uma Psicologia naturalmente aplicada a determinadas instituições e práticas. O argumento dessa disjunção entre "teoria" e "prática" será radicalizado em Folie et Déraison, compondo a própria estrutura do livro. Durante a "época clássica", as práticas de confinamento dos desrazoados não supunham um

${ }^{114}$ FOUCAULT, Dits et Écrits (Vol. I), p. 177.

115 Cf. MIOTTO, O problema antropológico em Michel Foucault.

${ }^{116}$ CANGUILHEM, L'Objet de l'Histoire des Sciences, p. 18. 
projeto ou saber médico (Parte I do livro), e por outro lado, as teorias e saberes classificatórios descreviam a loucura no "Jardim das Espécies" médicas, sem a necessidade de recorrer à observação dos loucos confinados (capítulos da Parte II). Nas palavras de Foucault, apenas por uma curiosa "confusão" histórica (Parte III) a análise racional da loucura e o espaço concreto do confinamento dos loucos acabam se justapondo, inaugurando então o Homo psychologicus e os projetos de psicologia. É uma espécie de "confusão" porque não se tem um médico que, por alargamento do método científico, faz avançar o caráter descritivo do internamento do louco rumo a um método experimental; e não se teria, por outro lado, um espaço confinatório que aguardava a formalização possível de uma racionalidade médica. Pelo contrário, tem-se um jogo histórico no qual, por demandas não médicas, o médico é primeiro chamado à instituição enclausuradora na figura de um administrador, para apenas em momentos posteriores encarregar-se de outras interrogações, não apenas administrativas mas também médicas e científicas. Nas palavras de Foucault, por ex.,

é a primeira vez [durante o século XVIII] que se encontram confrontados sistematicamente a loucura internada e a loucura tratada [soignée], a loucura ligada à desrazão e a loucura ligada à doença; resumindo, é o primeiro momento dessa confusão, ou dessa síntese (como se queira chamar), que constitui a alienação mental no sentido moderno da palavra.

[c 'est la première fois [durante o século XVIII] que se trouvent confrontées systématiquement la folie internée et la folie soignée, la folie rapportée à la déraison et la folie rapportée à la maladie; bref, le premier moment de cette confusion, ou de cette synthèse (comme on voudra l'appeler) qui constitue l'aliénation mentale au sens moderne du mot $]^{117}$.

e também

E durante muito tempo o que se chama tradicionalmente de "psiquiatria clássica" de uma forma aproximativa a que vai de Pinel a Bleuler - formará conceitos que no fundo não são mais do que compromissos, incessantes oscilações entre esses dois domínios da experiência que o século XIX não conseguiu unificar: o campo abstrato de uma natureza teórica na qual se destacam os conceitos da teoria médica; e o espaço concreto de um internamento artificialmente estabelecido, no qual a loucura começa a falar por si própria.

[Et pendant longtemps ce qu'on appelle traditionnellement la "psychiatrie classique" - d'une manière approximative celle qui va de Pinel à Bleuler - formera des concepts qui ne sont au fond que des compromis, d'incessantes oscillations entre ces deux domaines d'expérience que le XIX ${ }^{\mathrm{e}}$ siècle n'est pas parvenu à unifier: le champ abstrait d'une nature théorique dans laquelle on découpe les concepts de la théorie

${ }^{117}$ FOUCAULT, Histoire de la Folie à l'Age Classique, p. 452. 
médicale; et l'espace concret d'un internement artificiellement établi où la folie commence à parler pour elle-même. ${ }^{118}$

O Foucault de 1957 não é exatamente o de Folie et Déraison, mas é possível antever o sentido pelo qual ele enxerga, nas relações entre as psicologias e as outras ordens de práticas, uma conjunção problemática entre fatores heterogêneos, disjuntivos, detentores de consistência própria, e não uma progressiva acomodação ou ajuste. A prática científica se rege pelos conceitos da ciência (algo que a "escolha" do psicólogo por uma prática psicológica "científica ou não" exclui, gerando o velho tema da "crise de identidade" em Psicologia), mas Foucault julga encontrar boas razões para detectar na Psicologia - essa ciência de "perfil epistemológico baixo"" - relações disjuntivas com fatores não-científicos, até então não investigadas. Por isso o vínculo negativo com a prática e os inúmeros desdobramentos e reviravoltas apresentados em La Recherche Scientifique et la Psychologie: a formação de pesquisador não é suficiente para a inserção do psicólogo na prática, e os espaços práticos - que deveriam ser os mais interessados pelo saber da pesquisa - não requerem necessariamente o papel do savant psicólogo. A formação de pesquisador clínico, escolar ou do trabalho não garante, paradoxalmente, a inserção natural na prática (gerando, aliás, o tema de que a resistência à atuação do psicólogo constitui um dos traços positivos de sua prática ${ }^{120}$ ), e essa independência da prática não a faz funcionar de modo que defina "exigências precisas em relação à pesquisa científica"

Mesmo práticas encaradas como vizinhas da Psicologia, como a Medicina, seriam historicamente impermeáveis à Psicologia não por simples fenômeno de acomodação, de ajuste a ser vencido, mas por questão de não-identidade epistemológica. Desde Maladie Mentale et Personnalité (o argumento perdura na edição de 1962 de Maladie Mentale et Psychologie), Foucault tentava defender que a Psicopatologia não fornece à Psicologia o mesmo que a Fisiologia dava à Medicina. Em medicina orgânica é possível ao mesmo tempo estabelecer

118 FOUCAULT, Histoire de la Folie à l'Age Classique, p. 414.

${ }^{119}$ FOUCAULT, Dits et Écrits (Vol. II), p. 141.

${ }^{120}$ Usando o exemplo de Paul Guillaume, Canguilhem dizia que a "resistência à prática" acusaria ao psicólogo um caráter não-científico e "instrumental". Eis que Foucault mostra, nessa espécie de disjunção constitutiva entre "teoria" e "prática", o recurso sempre possível de usar a negação, a resistência, a impossibilidade da ação, como um valor "positivo".

${ }^{121}$ FOUCAULT, Dits et Écrits (Vol. I), p. 175. Por exemplo: a psicologia da escola pretende dizer certa "verdade" psicológica sobre a "prática" pedagógica. Mas apesar do grande número de escolas francesas, as vagas para psicólogos escolares na época de Foucault seriam pouco numerosas, embora dezenas de diplomas de psicologia escolar se distribuíssem anualmente. Isso não exporia apenas uma deficiência de postos de trabalho ou a "irrelevância" das formações (o que seria questão em qualquer área), mas certa disjunção da prática com o saber psicológico (Cf. FOUCAULT, Dits et Écrits (Vol. I), p. 174-175). Considerando o argumento de Foucault, em tese os conceitos psicológicos deveriam ser para a prática psicológica (por ex., escolar) o que, por ex., a pesquisa em Química deveria ser para a prática química (por ex., em âmbito puro, como no laboratório, ou aplicado, como na química industrial). Mas seria possível pensar "naturalmente” na prática escolar sem psicólogos escolares, a clínica sem psicólogos clínicos ou o trabalho sem psicólogos selecionadores, enquanto seria impossível pensar uma indústria química sem... aquele que faz química. Nas palavras de Foucault, por ex., "le psychologue qui, à l'institut, a reçu une formation technique suffisante pour l'exercice d'un métier psychologique, mais insuffisante certainement pour devenir un chercheur, n'a d'autre ressource, pour pratiquer la psychologie, que de demander une bource au CNRS, e de se lancer dans la recherche" (FOUCAULT, Dits et Écrits (Vol. I), p. 175). 
processos de conjunto e abstrair elementos individuais objetivamente descritíveis (uma lesão intestinal tem um estatuto na febre tifóide e outro num distúrbio suprarrenal, mas em cada qual dos casos permanece isolável sob a consistência objetiva de uma lesão intestinal), enquanto em Psicologia noções como a de "unidade significativa das condutas" carregariam consigo o sentido inteiro de qualquer manifestação individual ${ }^{122}$ (basta lembrar do tema freudiano: raramente um charuto "é apenas um charuto"). Igualmente, em medicina uma descrição objetiva de processos permitiria anexar a noção de "anormal" aos processos normais do organismo, segundo "reações adaptativas de um organismo funcionando segundo sua norma" "123; já em Psicopatologia, não haveria descrições precisas de processos, autorizando então classificações arbitrárias e a manutenção do anormal sob o signo do negativo e do "monstruoso". Finalmente, enquanto a medicina orgânica preservaria a diferença entre a identidade do doente e as medidas relativas à doença, em Psicologia as práticas do meio não implicariam apenas na ocorrência de uma doença (como por ex. a malária, que desaparece frente a medidas sanitárias), mas de sua existência (como no caso da personagem da histérica, tornada possível pelas práticas do século XIX e desaparecendo "à medida que se atenuam as práticas da sugestão que constituíam outrora o meio do doente"124). A Medicina é epistemologicamente - e não apenas institucionalmente resistente à Psicologia. Essas críticas permanecem com teor semelhante no texto de 1957:

Poderia-se citar nesse sentido a estranha impermeabilidade da medicina à psicologia; (...) Ligada a esse equívoco entre a técnica de cura e a realidade do fato patológico, encontra-se a ideia de que a patologia se desdobra como a manifestação concreta, como o fenômeno do anormal. O anormal é a essência da doença, cuja terapêutica é a supressão efetiva; como redução da essência do anormal ao processo normal, a técnica de cura constitui a medida indispensável da existência da doença. Resistindo à penetração da psicologia, a medicina (...) não se opõe apenas a uma retificação de seus métodos e de seus conceitos, mas sobretudo a uma retomada de questão do sentido real da doença e do valor absoluto do fato patológico. (...) eles defendem a doença como uma coisa, como sua coisa. Esquivando-se do problema do anormal, valorizando como instrumentos terapêuticos condutas como a linguagem ou a realização simbólica, a psicologia irrealiza o anormal e "sutiliza" a doença; aos olhos dos médicos e no desenvolvimento histórico da medicina, ela só pode ser, e ela é efetivamente, um empreendimento mágico.

[On pourrait citer dans ce sens l'étrange imperméabilité de la médecine à la psychologie; (...) Liée à cette équivoque entre la technique de guérison et la réalité du fait pathologique, on trouve lidée que le pathologique se déploie comme la manifestation concrète, comme le phénomène de l'anormal. L'anormal est l'essence de la maladie, dont la thérapeutique est la suppression effective; comme réduction de l'essence de l'anormal au processus normal, la technique de guérison constitue la mesure indispensable de l'existence de la maladie. En résistant à la pénétration de la

122 Cf. FOUCAULT, Maladie Mentale et Personnalité, p. 12-13.

${ }^{123}$ FOUCAULT, Maladie Mentale et Personnalité, p. 14.

${ }^{124}$ FOUCAULT, Maladie Mentale et Personnalité, p. 16. 
psychologie, la médecine (...) ne s'oppose pas seulement à une rectification de ses méthodes et de ses concepts, mais surtout à une remise en question du sens réel de la maladie et de la valeur absolute du fait pathologique. (...) ils defendent la maladie comme une chose, comme leur chose. En esquivant le problème de l'anormal, en valorisant comme instruments thérapeutiques des conduites comme le langage ou la réalisation symbolique, la psychologie irréalise l'anormal et "subtilise" la maladie; aux yeux des médécins et dans le développement historique de la médecine, elle ne peut être, et elle n'est effectivement, qu'une entreprise magique. ${ }^{125}$

Começa-se a ver reiteradamente que, para o Foucault de 1957, o princípio que define a distribuição das Psicologias num campo disperso, ou mesmo em suas relações com a prática e com outros saberes, perpassa a questão ainda não esclarecida da negatividade. A relação negativa com a prática também faz entrever dois outros fatores:

Em primeiro lugar, em relação à eficácia: Canguilhem dizia que, para se definir, a Psicologia não pode apelar à simples eficácia - que se não é "ilusória", pode ser "mal fundada" -, sob o risco de não passar de um "empirismo composto, literariamente codificado para fins de ensino" "126. Outro argumento era o do homem-instrumento: Canguilhem denunciava o perigo das psicologias se transformarem em práticas sem "nenhuma ideia que garanta seu sentido" 127 . Diante disso, Foucault responderia que certo apelo à eficácia e à posição de expertise são um efeito a mais, até constitutivo, desse caráter singular da Psicologia em suas relações com outras práticas. Conforme mencionado, a ausência de vínculo necessário com a prática e o movimento de trazer ordenamentos técnicos a práticas autonomamente pré-existentes garantiu muitas vezes o tema de que a Psicologia poderia ser naturalmente aplicável a qualquer prática. Isso, inclusive, garantiu muitas vezes à Psicologia outros temas, como o de uma "positividade imediata" e o de um ar de independência frente a qualquer especulação. O "empirismo composto" advertido por Canguilhem não seria, assim, apenas um risco, mas algo assumido como uma espécie de vantagem irrestrita, pois aplicável em qualquer âmbito, bastando apenas que a expertise seja eficaz para se comprovar como válida:

Não se aborda a pesquisa com uma formação de pesquisador e depois da aquisição de um horizonte teórico suficiente [é o que faz toda ciência]; faz-se da pesquisa na prática rechaçada, para mostrar antes de tudo que a psicologia pode e deve ser praticada, que ela não é prisioneira de um contexto teórico, inútil e duvidoso, mas que fora de todo postulado especulativo ela é carregada de uma positividade imediata; e se a pesquisa se inscreve com tanta frequência num contexto positivista, se ela afirma constantemente ser uma prática real, por oposição à psicologia filosófica, é justamente na medida em que ela quer ser a demonstração de uma prática possível.

125 FOUCAULT, Dits et Écrits (Vol. I), p. 178.

${ }^{126}$ CANGUILHEM, "Qu'est-ce que la Psychologie?”, p. 77.

${ }^{127}$ CANGUILHEM, "Qu'est-ce que la Psychologie?”, p. 90. 
[On n'aborde donc pas la recherche avec une formation de chercheur et après l'acquisition d'un horizon théorique suffisant; on fait de la recherche en praticien refoulé, pour montrer avant tout que la psychologie peut et doit être pratiquée, qu'elle n'est pas prisionnière d'un contexte théorique, inutile et douteux, mais qu'en dehors de tout postulat spéculatif elle est chargée d'une positivité immédiate, et si la recherche s'inscrit si souvent dans un contexte positiviste, si elle se réclame constamment d'une pratique reélle, par opposition à la psychologie philosophique, c'est dans la mesure justement où elle veut être la démonstration d'une pratique possible] ${ }^{128}$.

Se a Psicologia teve para muitos intérpretes certo caráter de anarquismo epistemológico, para Foucault isso não seria reflexo de questões mal colocadas, de uma ciência ainda em juventude, de práticas virtualmente formalizáveis ou de uma positividade difícil de conquistar devido à complexidade de seu objeto, mas sim fruto das relações historicamente negativas e disjuntivas entre os conceitos e as práticas. Relações que, não obstante, sob outros temas permitiram garantia irrestrita para que psicologias diferentes se aplicassem igualmente e proliferassem em qualquer contexto (e não à toa qualquer prática pode ser abordável por qualquer teoria, de onde brotam os temas da "escolha teórica" que independe de qualquer domínio de positividade). A epígrafe citada de Morère - do " há psicólogos" - é coroada pela ironia de Foucault, que afirma: "No momento em que se é psicólogo, se pesquisa. O quê? O que os outros pesquisadores deixarem pesquisar, pois não se pesquisa para encontrar, mas para pesquisar, por ter pesquisado, por ser pesquisador", ou em outras palavras, uma vez que não é uma racionalidade científica que põe a existência da pesquisa psicológica, mas é a pesquisa que "escolhe" ou não por uma racionalidade científica aplicável em contextos historicamente exógenos, pode-se então "escolher" por qualquer pesquisa, "sobre as neuroses do rato, sobre a frequência estatística das vogais na versão inglesa da Bíblia, sobre as práticas sexuais da mulher de subúrbio, nas lower middle class exclusivamente (...)" ${ }^{\prime 129}$.

Em segundo lugar, não obstante o apelo à "positividade imediata" e a desenvoltura para com a prática, ou talvez por esses fatores mesmos, Foucault detecta em Psicologia um engajamento conceitual bastante particular. Retornando a Pagès, um conceito regedor para a Psicologia não precisaria ter, "nele mesmo", "nenhuma tendência a se especificar numa filosofia do homem-instrumento", bastando "escolhas pessoais" para alterar o uso da ciência, aliená-la em maus propósitos ou não ${ }^{130}$; igualmente, a Psicologia pode levar o indivíduo tanto à adaptação ao meio quanto do meio ${ }^{131}$. É certo que "a maior parte dos psicólogos profissionais contemporâneos praticam uma técnica escravizante", embora, como vimos, não há "um vínculo de tipo lógico entre o domínio e os métodos da psicologia, de uma parte, e uma filosofia do homem-instrumento, de outra" ${ }^{\prime 132}$. Enfim, conforme dito, a Psicologia, como qualquer outra ciência, poderia ter seu uso alienável, embora em si mesma não o seja.

\footnotetext{
${ }^{128}$ FOUCAULT, Dits et Écrits (Vol. I), p. 175.

${ }^{129}$ FOUCAULT, Dits et Écrits (Vol. I), p. 184.

130 PAGÈS, “Quelques remarques sur 'Qu'est-ce que la psychologie?"”, p. 93.

131 PAGÈS, “Quelques remarques sur 'Qu'est-ce que la psychologie?"”, p. 95.

132 PAGÈS, “Quelques remarques sur 'Qu'est-ce que la psychologie?"”, p. 96.
} 
O texto de Foucault ataca esses princípios (o de que a ciência em si seria neutra, mas alienável para propósitos escusos), tomando o exemplo da Psicologia do Trabalho. Ela se encarrega de seleção e orientação, ou da adaptação ao meio laboral. Escreve Foucault: apenas num período de pleno emprego e de alta especialização tais técnicas seriam algo mais do que uma discriminação. Mas esse ainda é um argumento de "usabilidade" e não residiria aí o essencial. É certo, conforme também sustentaria Pagès, que as técnicas e ciências são alienáveis e aplicáveis segundo critérios econômicos e sociais. Mas tome-se a Física ou a Química: seja qual for a situação econômica, "os corpos continuam a cair e os elétrons a girar", isto é, independente de sua aplicabilidade (ou deturpação possível no uso prático) os conceitos científicos permanecem enquanto tais, inerentes às racionalidades que lhes dão conteúdo e sentido. Mas em Psicologia ocorrem decisões mais sérias:

Em psicologia, quando as condições de uma prática racional e científica não estão reunidas, é a própria ciência que é comprometida em sua positividade; em período de desemprego e de superprodução, a seleção cessa de ser uma técnica de integração para se tornar uma técnica de exclusão e de discriminação; em período de crise econômica ou de aumento do preço do trabalho, a adaptação do homem a seu trabalho se torna uma técnica que visa a aumentar a rentabilidade da empresa e a racionalizar o trabalho humano como puro e simples fator de produção; resumindo, ela deixa de ser uma técnica psicológica para se tornar uma técnica econômica.

O que não quer dizer simplesmente que ela é utilizada para fins econômicos ou motivada para propósitos econômicos, este é o destino de todas as ciências aplicadas. Queremos dizer, por exemplo, que a noção de aptidão, tal como utilizada em psicologia industrial, muda de conteúdo e sentido segundo o contexto econômico no qual se é conduzido a defini-la.

[En psychologie, lorsque les conditions d'une pratique rationnelle et scientifique ne sont pas réunies, c'est la science elle-même qui est compromise dans sa positivité; en période de chômage et de surproduction, la sélection cesse d'être une technique d'integration pour devenir une tecnique d'exclusion et de discrimination; en période de crise économique ou d'augmentation du prix du travail, l'adaptation de l'homme à son métier devient une technique qui vise à augmenter la rentabilité de l'entreprise et à rationaliser le travail humain comme pur et simple facteur de production; bref, elle cesse d'être une technique psychologique pour devenir une technique économique.

Ce qui ne veut pas dire seulement qu'elle est utilisée à des fins économiques ou motivée par des propos économiques, c'est le destin de toutes les sciences appliquées. Nous voulons dire, par exemple, que la notion d'aptitude, telle qu'elle est utilisée en psychologie industrielle, change de contenu et de sens selon le contexte économique dans lequel on est amené à la définir.] ${ }^{133}$

Não se trata apenas de alienar o uso da ciência ou aplicá-la segundo critérios econômicos, mantendo seus conceitos e racionalidade enquanto tais, "neutros". Em 
Psicologia trataria-se de alienar a própria ciência, de "dar um estatuto, ao nível de psicologia individual, a necessidades históricas, sociais ou econômicas". Seus conceitos mudam de "conteúdo e sentido" - enfim, muda a economia da própria existência de um conceito conforme o contexto, argumento não apenas detectável sob a noção de "aptidão", mas em diversas outras (o exemplo acima, de que a existência ou não da personagem da histérica é diretamente relacionada a certas práticas institucionais, reforça a mesma ideia). Não temos aqui ainda o Foucault "genealogista", que ampliará a análise rumo a toda ciência e filosofia para dizer que "o Ocidente será dominado pelo grande mito segundo o qual a verdade não pertence jamais ao poder político" "134. Mas esse vínculo negativo da Psicologia em relação às outras ciências e práticas abre as portas para analisar esse curioso estatuto.

Disso tudo, já se fez notar que, segundo o Foucault de 1957, a psicologia inteira é animada pelo problema do negativo. Vale repetir: Canguilhem alertava ao perigo da falta de fundamento da psicologia fazê-la recair numa psicotécnica, no homem-instrumento, e Robert Pagès respondia que qualquer ciência também pode ser aplicada a qualquer propósito. De fato, considerando Canguilhem, as psicologias podem ter um vínculo não elucidado com a prática, mas considerando Robert Pagès, as psicologias podem igualmente ser discriminatórias ou emancipadoras: se elas podem alienar e instrumentalizar o homem, elas também poderiam libertá-lo, pois afinal, “o saber não tem odor”. Mas em Foucault, ainda nesse ponto há algo mais, um estatuto constitutivo da Psicologia: bem ou mal utilizadas, alienantes ou libertárias de fato ou de direito, as psicologias não se desvinculam de uma análise pautada na negatividade e na contradição humanas. O negativo é o que dá alma à Psicologia e o que a distingue das outras matérias. Não à toa o louco, o anormal e o desviante sempre foram objetos privilegiados, e o negativo pode ser visto em filigrana em todas as psicologias:

é do ponto de vista do inconsciente que se torna possível uma psicologia da consciência que não seja pura reflexão transcendental, do ponto de vista da perversão que uma psicologia do amor é possível sem que seja uma ética; do ponto de vista da estupidez uma psicologia da inteligência pode se constituir sem um recurso, pelo menos implícito, a uma teoria do saber; é do ponto de vista do sono, do automatismo e do involuntário que se pode fazer uma psicologia do homem desperto e percebendo o mundo, que evita se fechar em uma pura descrição fenomenológica. Sua positividade, a psicologia empresta das experiências negativas que o homem faz de si mesmo ${ }^{135}$.

, ou ainda, à luz deste trecho sobre La Recherche Scientifique et la Psychologie, pode-se compreender inteiramente um outro trecho, alusivo e pouco trabalhado, de La Psychologie de 1850 à 1950:

É igualmente no curso dos cem últimos anos que a psicologia instaurou relações novas com a prática: educação, medicina mental, organização de grupos. Ela se apresentou como seu fundamento racional e científico; a psicologia genética se

${ }^{134}$ FOUCAULT, Dits et Écrits (Vol. I), p. 1438.

${ }^{135}$ FOUCAULT, Dits et Écrits (Vol. I), p. 180-181. 
constituiu como o quadro de toda pedagogia possível, e a psicopatologia se ofereceu como reflexão sobre a prática psiquiátrica. Inversamente, a psicologia se colocou como questões os problemas levantados por essas práticas: problema do abandono e do fracasso escolar, problema da inserção do doente na sociedade, problema da adaptação do homem a seu trabalho. Por esse vínculo estreito e constante com a prática, por essa reciprocidade de suas trocas, a psicologia se torna semelhante a todas as ciências da natureza. Mas estas não respondem nunca senão a problemas colocados pelas dificuldades da prática, seus fracassos temporários, as limitações provisórias de sua experiência. A psicologia, em contraparte, nasce nesse ponto no qual a prática do homem reencontra sua própria contradição; a psicologia do desenvolvimento nasceu como uma reflexão sobre as interrupções do desenvolvimento; a psicologia da adaptação como uma análise dos fenômenos de inadaptação; a da memória, da consciência, do sentimento apareceu de saída como uma psicologia do esquecimento, do inconsciente e das perturbações afetivas. Sem forçar com exatidão, pode-se dizer que a psicologia contemporânea é, em sua origem, uma análise do anormal, do patológico, do conflitual, uma reflexão das contradições do homem consigo mesmo.

[C’est également au cours de ces cent dernières années que la psychologie a instauré des rapports nouveaux avec la pratique: éducation, médecine mentale, organisation des groupes. Elle s'est présentée comme leur fondement rationnel et scientifique; la psychologie génétique s'est constituée comme le cadre de toute pédagogie possible, et la psychopathologie s'est offerte comme réflexion sur la pratique psychiatrique. Inversement, la psychologie s'est posé comme questions les problèmes que soulevaient ces pratiques: problème de la reussite et de l'échec scolaire, problème de l'insertion du malade dans la société, problème de l'adaptation de l'homme à son métier. Par ce lien serré et constant avec la pratique, par cette réciprocité de leurs échanges, la psychologie se rend semblable à toutes les sciences de la nature. Mais celles-ci ne répondent jamais qu'à des problèmes posés par les difficultés de la pratique, ses échecs temporaires, les limitations provisoires de son expérience. La psychologie, en revanche, nait en ce point où la pratique de l'homme rencontre sa propre contradiction; la psychologie du développement est née comme une réflexion sur les arrêts du développement; la psychologie de l'adaptation comme une analyse des phénoménes d'inadaptation; celle de la mémoire, de la conscience, du sentiment est apparue d'abord comme une psychologie de l'oubli, de l'inconscient et des perturbations affectives. Sans forcer l'exactitude, on peut dire que la psychologie contemporaine est, à son origine, une analyse de l'anormal, du pathologique, du conflictuel, une réflexion sur les contradictions de l'homme avec lui même.] ${ }^{136}$

Note-se o realce de Foucault na diferença entre a Psicologia e os outros campos de positividade, requerendo uma análise específica da questão do negativo. Tanto ocorre assim que se poderia evocar um debate em torno do destino desses argumentos no Foucault dos anos 1960 e nas considerações de Canguilhem sobre Kant. Na conferência Canguilhem diz

${ }^{136}$ FOUCAULT, Dits et Écrits (Vol. I), p. 150. 
que, em Kant, o destino da Psicologia é situar-se numa Antropologia, compreendida como "teoria geral da habilidade humana que permanece ligada a uma teoria da sabedoria"137. Esse mesmo tema será um dos principais da Tese Complementar, pois para Foucault, caso se siga o "ensinamento" das Críticas, em Kant tanto a Psicologia Empírica, quanto a Racional, teriam como espécie de destino uma Antropologia pragmática. Em Kant, a "antropologia” definiria a "exploração" (Erforschung) de um nível de análise concreta do homem como ser que age livremente em meio ao mundo e aos outros homens. Para Foucault, Kant não incorreria numa redução das funções fundantes do sujeito a um nível empírico. Isso seria entrevisto pelas "antropologias fisiológicas" do século XVIII-XIX, responsáveis por estudar "o que a natureza faz do homem", e não o que o homem "faz de si mesmo" ${ }^{138}$, nível este do próprio Kant. Se em Canguilhem a Psicologia recai numa Antropologia kantiana como "théorie de la sagesse", em Foucault o esforço é de mostrar como Kant, mesmo no que chama de "antropologia pragmática", contorna as Psicologias em direção a uma Antropologia para preservar os ensinamentos da Crítica. Inclusive Foucault mostra que esses novos estudos "fisiológicos" sobre o Homem, que despontam desde o fim do século XVIII, também seriam profundamente marcados pela questão do negativo: enquanto livros como os Princípios Metafísicos da Ciência da Natureza "dispensam Deus e tornam inútil a hipótese de um infinito atual, cuja contradição externa foi mostrada pela Crítica", a negatividade e normatividade da Antropologia "aponta a ausência de Deus, e se desenvolve no vazio deixado por este infinito"139. Em suma: segundo a Tese Complementar, o estudo do Homem se torna possível quando, com o fim da metafísica, surge a possibilidade do homem enredar-se em análises "antropológicas", tomando-se ao mesmo tempo como fundamento do conhecimento e elemento empírico. As modulações do negativo em Psicologia seriam exemplares privilegiados de tal possibilidade. Via Kant, o contorno das Psicologias e a análise da negatividade permitiriam - para Foucault - entrever inclusive uma mudança na tarefa do Filosofar, que iria da crítica aos dogmatismos à crítica aos antropologismos (ancorada - não esqueçamos - também na filosofia de Nietzsche).

Dados todos esses fatores, pode-se afirmar que entre 1954 e 1957, e sob questões correlatas às evocadas pela conferência de Canguilhem sobre a Psicologia, a "inquietude" acima mencionada resultou em Foucault numa suspeita: será por acaso que a psicologia se anima em torno do problema do negativo? E se é assim, qual seria o estatuto dessa negatividade? Ela parece definir um fundo histórico no qual não seria mais um debate epistemológico dirigido à questão dos direitos científicos o que daria conta das dispersões da Psicologia. Qual rumo então seguir? O texto de 1957 termina:

Se a psicologia quisesse reencontrar seu sentido ao mesmo tempo como saber, como pesquisa e como prática, ela deveria se afastar desse mito de positividade diante do qual hoje ela vive e morre, para encontrar seu espaço próprio no interior das

${ }^{137}$ CANGUILHEM, “Qu'est-ce que la Psychologie?”, p. 91.

${ }^{138}$ KANT, Antropologia de um ponto de vista pragmático, p. 21.

${ }^{139}$ FOUCAULT, Introduction à l'Anthropologie de Kant, p. 75-76. 
dimensões da negatividade do homem (...) [de onde] a psicologia não se salvará senão por um retorno aos Infernos ${ }^{140}$.

Em Foucault, nos textos de 1957 a importância da história impõe uma questão: a de como, sob determinadas circunstâncias que convém esclarecer, o homem instituiu na relação consigo e com os outros homens certa distância, oferecida em primeiro lugar como negatividade e depois como saber. Os caminhos dessa questão são percorridos por Foucault desde Folie et Déraison e a Introduction à l'Anthropologie de Kant. Conforme entrevisto acima, isso tudo se insere no campo do debate entre Canguilhem e Pagès em diversos níveis. Além disso, abre a análise epistemológica da Psicologia em direção a uma "arqueologia" da modernidade.

\section{FROM CANGUILHEM TO FOUCAULT BY WAY OF PSYCHOLOGY}

Abstract: The purpose of the present work is to compare the debate between the Philosopher Georges Canguilhem and the Psychologist Robert Pagès regarding the conference Qu'est-ce que la Psychologie?, held on 1956, with the published texts of Michel Foucault during the decade of 1950. In order to do that, the article begins with some historical notes, followed by a brief analysis of Foucauldian texts of 1954, Maladie Mentale et Personnalité and Introduction à Le Rêve et l'Existence. The Foucauldian texts are then confronted with Canguilhem-Pagès debate, which are analyzed and compared with two other published texts by Foucault in 1957: La Psychologie de 1850 à 1950 and La Recherche Scientifique et la Psychologie. The aim of the present work is to demonstrate that the beginning of Foucault's career not only maintain a certain interlocution with the questions presented by Canguilhem and Pagès around Psychology, but even rehearse some critical directions which full content can be viewed in both thesis defended by Foucault, Folie et Déraison and Introduction à l'Anthropologie de Kant.

Keywords: Michel Foucault - Georges Canguilhem - Robert Pagès - Psychology - Human Sciences - Contemporary French Philosophy.

\section{REFERÊNCIAS BIBLIOGRÁFICAS}

BERNARD, M. (1973) A Psicologia. In: História da Filosofia - Idéias, doutrinas (org. de François Chatelet). Vol. VII - A Filosofia das Ciências Sociais. Rio de Janeiro: Zahar Editores, 1974.

BINSWANGER, L. "O sonho e a existência”. Natureza Humana v. 4, n. 2, p. 417-449. São Paulo: dez. 2002. Disponível em http://pepsic.bvsalud.org/scielo.php?script=sci arttext\&pid=S1517$24302002000200007 \& \operatorname{lng}=$ pt\&nrm $=$ iso

BRAUNSTEIN, Jean-François. "La Critique Canguilhemienne de la Psychologie". Bulletin de Psychologie, Tome 52 (2), 440, Mars-Avril 1999.

CANGUILHEM, G. "Qu'est-ce que la Psychologie?”. Cahiers pour l'analyse, n. 2, março de 1966 (original de 1956).

L’Objet de l'Histoire des Sciences. Études d'Histoire et de Philosophie des Sciences. Paris: Vrin, 1994.

${ }^{140}$ FOUCAULT, Dits et Écrits (Vol. I), p. 186. 
ERIBON, D. Michel Foucault (1926-1984). São Paulo: Martins Fontes, 1990.

FOUCAULT, M. Maladie Mentale et Personnalité. Paris: PUF, 1954.

. Maladie Mentale et Psychologie. Paris: PUF, 1962.

. Histoire de la Folie à l'Age Classique. Paris: Gallimard, 1972.

Dits et Écrits (Vol. I). Paris: Gallimard, 2001.

Dits et Écrits (Vol. II). Paris: Gallimard, 2001b.

(1961) Introduction à l'Anthropologie de Kant. In: KANT, I. Anthropologie d'un point de vue pragmatique. Paris: Vrin, 2008.

GROS, Frédéric. Foucault et la Folie. Paris: PUF, 1997.

HEIDELBERGER, Michael. Some patterns of change in the Baconian Sciences of the early 19th century Germany. In: Epistemological and Social Problems of the Sciences in the Early Nineteenth Century (org. JAHNKE, H.N.; OTTE, M.) Papers from a workshop held at the University of Bielefeld, Nov. 2730, 1979, and sponsored by its Institute for the Didactics of Mathematics. D. Reidel Publishing Company: Dordrecht, Boston e Londres, 1981.

HUISMAN, Denis. "Note sur l'article de Michel Foucault”. Revue Internationale de Philosophie. Vol. 44 n. $1732 / 1990$ p. 177.

KANT, I. (1798) Antropologia de um ponto de vista pragmático (trad. Clélia Aparecida Martins). São Paulo: Iluminuras, 2006.

MACEY, David. Las Vidas de Michel Foucault. Madrid: Catedra, 1995.

MIOTTO, M. O problema antropológico em Michel Foucault. Tese de Doutorado apresentada à PósGraduação em Filosofia da UFSCAR. São Carlos: UFSCAR, 2011. https://philpapers.org/rec/MIOOPA

PAGÈS, Robert. “Quelques remarques sur 'Qu'est-ce que la psychologie?'”. Cabiers pour l'analyse, n. 2, março de 1966 (original de 1956).

PALTRINIERI, L. De quelques sources de Maladie Mentale et Personnalité. Réflexologie pavlovienne et critique sociale. In: Foucault à Munsterlingen (org. BERT, Jean-François; BASSO, Elisabetta). Paris: Éditions EHESS, 2015.

PESTAÑA, José Moreno. Convirtiéndose en Foucault. Sociogénesis de un filósofo. Madrid, Montesinos, 2006 ROUDINESCO, Elisabeth. Philosophy in turbulent times: Canguilhem, Sartre, Foucault, Althusser, Deleuze, Derrida. New York: Columbia University Press, 2008. 